\title{
JUDITA I DRUGE ŽENE U HRVATSKIM RENESANSNIM I BAROKNIM KNJIŽEVNIM DJELIMA
}

Jasminka Brala-Mudrovčić

UDK: 821.163.42.09“15/16“

Željka Štrkalj

Sveučilište u Zadru

Odjel za nastavničke studije u Gospiću

821.163.42.09-055.2

Izvorni znanstveni članak

Dr. A. Starčevića 12

HR 53000 Gospić

jmudrovcic@unizd.hr

U radu se analizira široki spektar ženskih likova kod najpoznatijih hrvatskih renesansnih i baroknih autora. Promatranje likova vrši se s obzirom na determinante književnopovijesnog razdoblja, manire izražavanja i književne ideje ili svrhe lika unutar piščeve koncepcije svijeta. Renesansni autori su idealizirali žensku ljepotu, a barokni su je prikazali u dihotomnom obliku: kao izvor grešnosti (posljedica moralističke didaktičnosti), ali i izvor novih i smionih erotičnih imaginacija ili pak ideal duhovnih i etičkih vrlina. Uočeno je formiranje pet različitih tipova žena s obzirom na njihovu jaču realističku, simbolično-alegorijsku ili apstraktnu narav: petrarkističke gospoje, žene ratnice, dobre žene, žene bludnice i žene čarobnice. Posebno se proučio položaj Judite u promatranom korpusu. To djelo oduvijek je privlačilo pažnju književnih teoretičara, ali i jezikoslovaca jer se upravo njime hrvatska srednjovjekovna pismenost brzo transformirala u autorsku i nacionalnu literaturu.

Ključne riječi: renesansa, barok, gospoje, ratnice, dobre žene, bludnice, čarobnice

\section{Uvod}

Hrvatska renesansna i barokna književna djela kontinuirano postoje do danas na hrvatskoj književnoj sceni, o čemu svjedoči i sustavno i trajno pručavanje njihove umjetničke vrijednosti. Na toj ljestvici nesumnjivo prednjači Judita Marka Marulića, koja uživa recepcijsku trajnost i poticajnost. Nju se čitalo, objavljivalo, prevodilo, stručno obrađivalo i znanstveno tumačilo. Želja za očuvanjem spomena na staru hrvatsku čakavštinu i početke stvaranja hrvatskoga književnog jezika oduvijek je postojala, nesumnjivo zahvaljujući i zalaganju poznatih jezikoslovaca i istraživača Marulićevih djela, među kojima se posebno istaknuo akademik Milan Moguš. Moguš je pomno proučavao 
Marulićev leksik što je urodilo brojnim tekstovima i potpunim rječnicima Marulićevih djela. Višegodišnje bavljenje Marulićevim djelom, a posebno vrijednim epom, zaokruženo je Rječnikom Marulićeve Judite, ${ }^{1}$ kojim je Moguš cjelovito sagledao jezičnu problematiku i temeljito proučio značenjsku obuhvatnost riječi i tako svima omogućio zadovoljstvo razumijevanja stoljećima udaljenog umjetničkog teksta, koji je svoga autora učinio velikanom hrvatske književnosti. Opisi Juditine ljepote i njezinih priprema da zavede tiranskog vojskovođu, kao i njezine odlučnosti i hrabrosti izrazito su renesansnog karaktera. ${ }^{2}$ Osim opisa njezine ljepote, Judita je postala primjer hrvatskom narodu kako se u teškim vremenima treba boriti za svoj život i spas te kako se treba pouzdati u vlastite snage i nikada ne klonuti pred opasnošću ${ }^{3}$. Stoga se u ovom radu postavio izazov: proučiti položaj Judite u odnosu na položaj drugih istaknutih ženskih likova u razdoblju renesanse i baroka. Kako se položaj žena kroz povijest neprestano mijenjao, interes za proučavanjem položaja žena u književnosti postao je tim veći. Sva ta pručavanja temelje se na dragocjenim jezikoslovnim tumačenjima, poput Moguševa Rječnika koji nas je bogatstvom primjera spojio s Marulićevom riječi i tako nam odzrcalio duh vremena, duh grada i naroda u kojem je nastala.

Čovjek renesanse okreće se suncu da bi se afirmirao na posve nov način. ${ }^{4}$ U srednjem vijeku najviše se pjeva o Djevici Mariji, dok u renesansi pjesnici uzdišu za lijepom i uzoritom gospojom. I u renesansi je Djevica Marija književna junakinja, međutim, više nije daleka divinizirana žena, već je bliža čovjeku i podsjeća na gospoju iz petrarkističkih kanconijera pa samim time ljubav prema Djevici Mariji i ljubav prema gospoji postaju istovjetne. ${ }^{5} \mathrm{U}$ hrvatskoj renesansnoj književnosti Marko Marulić napisao je brojne marijanske pjesme i izvrsno je prepjevao najpoznatije marijanske himne s latinskog na hrvatski. ${ }^{6}$ Pored toga prepjevao je poznatu marijansku pjesmu Vergine bella iz Petrarkinog Kanconijera i objavio je na kraju Evangelistara. Također, Marulić slijedi hrvatskog glagoljaša popa Martinca koji piše Ištoriju vdove Ijuditi, opisujući njezinu ljepotu i hvaleći njezine duhovne vrline. Nadahnut time, Marulić piše Juditu u kojoj opjevava junakinju prema predlošku starozavjetne Knjige o Juditi, tako joj namjenjujući drugačiju ulogu od one koje su inače imale srednjovjekovne junakinje. Judita je




prikazana kao djelotvorna junakinja, a ne kao srednjovjekovna žena koja čeka da se dogodi čudo. Prikazana je i kao renesansna donna, svjetovna žena nove petrarkističke lirike kojoj pjesnik pridaje atribute kraljevske ljepote. Osim Judite Marulić iz Biblije uzima još jednu legendu po kojoj nastaje Historija od Suzane. Suzana je, poput Judite, ljepotica slična obožavanim vilama iz petrarkističkih kanconijera, a pjesnik opisuje njezinu zanosnu ljepotu, bijeli vrat, crne oči, milu glavicu i ostalo. Marulićevoj Suzani slična je i Vetranovićeva Suzana čista, u čije središte Vetranović stavlja sam čin suđenja. Ističe Suzaninu hrabrost i iskrenost. I Marulić i Vetranović koriste se biblijskim likom žene kako bi progovorili o svakodnevici i izrazili sumnju u pravednost onih koji su zaduženi za zaštitu pravnog poretka. ${ }^{7}$ Osim Marulićeve Judite i Vetranovićeve Suzane čiste dojmljiva je i Držićeva pjesma Draža je od zlata u kojoj se već od prvog stiha uspoređuje ljepota drage sa zlatom, proljećem, biserom i vilom. Njezina ljepota ne može se opisati ovozemaljskom ljepotom, ona je dana od Boga. Po istom modelu pisana je i pjesma Šiška Menčetića Blaženi čas $i$ hip. Prva hrvatska svjetovna drama Robinja Hanibala Lucića zbog naglašenih trubadurskopetrarkističkih elemenata ima više lirski nego dramski karakter, a već se u prvim stihovima zagovara brak na temelju vjerne ljubavi nasuprot braku temeljenu na materijalnim interesima. ${ }^{8}$ Nasuprot petrarkističkom veličanju žene nailazi se na Jeđupku Mikše Pelegrinovića koja otkriva čitavu galeriju likova jednog društva, čitavu lepezu bračnih odnosa i slučajeva, a pogotovo čitav zbir žena i djevojaka iz bogatijih plemićkih i građanskih slojeva. Marin Držić donosi komediju Dundo Maroje u kojoj prikazuje kurtizanu Lauru koja vreba mlade trgovce s novcem i time kao da strukturira prijelaz prema baroknom protureformacijskom kritičkom pogledu na lik žene-grešnice koja donosi propast.

U baroku dominantni su likovi žena u pastorali Dubravka, djelu Suze sina razmetnoga i epu Osman Ivana Gundulića, Vučićevoj religioznoj poemi Mandalijena pokornica, Đurđevićevim Uzdasima Mandalijene pokornice te Palmotićevim melodramama Pavlimir i Armida. Gundulić opisuje zlu i pohotnu ženu koja će upropastiti dotadašnji idealizirani pogled na ženski lik, a Gundulićev tip posrnule žene jednim dijelom sliči na Đurđevićevu i Vučićevu Mandalijenu, međutim ona je pokajana i obraćena, pa samim time i spašena. ${ }^{9}$ Palmotić u svoje melodrame uvodi, između ostalih, lik čarobnice koji je neuobičajen u baroknoj književnosti.

\footnotetext{
V. DELBIANCO, 2006, 135-148.

N. KOLUMBIĆ, 2005.

M. FRANIČEVIĆ et al., 1974.
} 
Analiza ženskih likova, koja slijedi, opravdat će postojeće predodžbe o liku žene u renesansi kao uzvišenoj gospoji te liku žene u baroku kao junakinji, bludnici ili čarobnici.

\section{Lik žene u hrvatskim renesansnim i baroknim književnim djelima}

\subsection{Judita}

Poezija Marka Marulića nastala je iz istih raspoloženja iz kojih i njegova latinska moralno-didaktična djela. Najviše topline nalazi se u njegovoj popularnoj Molitvi suprotiva Turkom, gdje se molitvom obraća Bogu da spasi svoj izmučeni narod. Međutim, najvažnije njegovo djelo je epski spjev Judita dovršen 1501. godine, a tiskan dvadeset godina kasnije. U spjevu je obrađena priča iz Sv. Pisma o Juditi i Holofernu, a raspoređena je u šest pjevanja. U Juditi, Marulić je kršćanski pjesnik koji s jedne strane grubim realizmom nesimpatično crta Holoferna i njegove vojvode, dok s druge strane aureolom obavija glavu glavne junakinje. ${ }^{10}$

Već od prvih stihova invokacije kroz molitve i moralne pouke izbija osnovna tendencija. Držeći se biblijske priče, Marulić svoju zamisao ostvaruje kroz legendu o hrabroj udovici koja je spasila svoj grad od osvajačke Nabukodonosorove vojske, hrabreći narod i ulijevajući mu nadu u spas u beznadnoj situaciji. ${ }^{11}$ Judita je prvi umjetnički ep u hrvatskoj književnosti i prva istinska poetska afirmacija hrvatskog jezika, nastala na domaćoj književnoj tradiciji. U Marulićevu rvanju s metrom i srokom, u traženju i kovanju potrebite poetske riječi, hrvatski je pjesnički jezik prelazio u viši razvojni stupanj, otkrivao se u neslućenim mogućnostima, pored svih nasuprotnih datosti (...). Sve to tvori njezin identitet, njezine prepoznatljive amplitude u autorskoj sklonidbi na više strukturnih planova, po kojima je i stekla epohalno značenje za našu kulturu i priskrbila pjesniku naziv 'oca hrvatske književnosti'. ${ }^{12}$ Marulić se strogo držao tijeka pripovijedanja u biblijskom tekstu, ali je samostalnim poetskim rješenjima djelu dao potrebnu dramatiku. Sve je podređeno osnovnoj ideji - kao hrabri pojedinac tog naroda, mudra i hrabra udovica Judita uspjela je zavarati častohlepnog asirskog vojskovođu Holoferna, ubiti ga i unijeti pomutnju u njegov tabor. Već u prvom pjevanju Marulić svjesno inzistira na detaljnom slikanju vojske u pokretu, ističući snagu i neuništivost. Nakon daljnjih osvajanja,

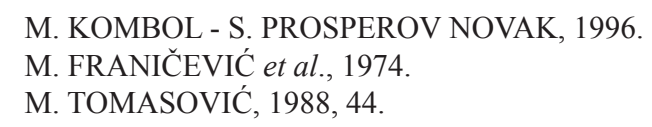


za vrijeme opsade Betulije nastupa Judita koja hrabri posustale građane i odluči se na gotovo nemoguć čin - poći u Holofernov tabor. Opis Juditine ljepote, ${ }^{13}$ dok se priprema za taj posjet ima svoju posebnu funkciju unutar spjeva. ${ }^{14}$ Na prvi pogled taj odlomak privlači pažnju opisom detalja Juditine odjeće i nakita, pri čemu se otkriva renesansna figura splitske vlastelinke. Marulićev pripovjedač ovdje se ograđuje od konotacija koje ima petrarkistički, ljubavno usmjeren opis ljepote. Rabeći brojne figure petrarkističke lirike kako bi što zornije prikazao Juditinu ljepotu i zaključujući taj opis sentencijom da Juditina fizička ljepota nije bila od bludi, sugerira čitatelju da taj opis prihvati u duhu kršćanskog shvaćanja ljepote. ${ }^{15}$ Marulić time ističe sekundarnu ulogu njezine nedvojbene tjelesne ljepote, jer su za epsko pjevanje mnogo važnije duhovne vrijednosti koje ona posjeduje. Međutim, u kontekstu četvrtog pjevanja, taj odlomak ima i svoju kompozicijsku funkciju jer pjesnik nastoji Juditu opisati bogato i svestrano, zbog čega će zaslijepiti Holoferna. Dodir s petrarkizmom očituje se u frazeologiji ${ }^{16}$ Holofernova prvoga susreta s njome. ${ }^{17}$

Osim opisa Juditine ljepote, iz trećeg pjevanja saznaje se mnogo o njezinoj pobožnosti, ali i hrabrosti. U trenutku kada su njezini sugrađani sve prepustili Božjoj volji, ona se oštro usprotivila njihovoj odluci da iskušavaju Njegovu volju te im govori kako će ih Bog spasiti jedino ako budu ustrajni, iz čega se saznaje kako je njezina vjera čvrsta i nepokolebljiva. Saznaje se kako

13 Splete glavu kosom, vitice postavi, / Kontušs s urehom svom vazam na se stavi; / S ošvom ruke spravi, uši s userezmi, / Na nogah čizmice s podvezmi. / S urehami tezmi, ča mi je viditi, / Dostojna bi s knezmi na sagu siditi; / I jošće hoditi na pir s kraljicami / I čtovama biti meu banicami. / Zlatimi žicami sjahu se poplici, / A trepetliicami zvonjahu uvici; / Stahu zlati cvici po svioni sviti, / Razlici, ne rici po skutih pirliti, / Svitlo čarljeniti ja rubin na parstih, / Cafir se modriti, bilitih na rukavih / Biser i na bustih, i sve od zlatih plas / Sjati se na bedrih prehitro kovan pas. / Velik urehe glas, da liposti veći, / Ka biše kako klasiz trave resteći, / Al kami, ki steći u zlato većma sja: / Tako t'ona prida uresi krasosti / Poveće ner prija od njeje liposti. / I to ne bi dosti, kako Pismo pravi, / Bog njeje svitlosti uljudstva pristavi; / Jer te take spravi ne bihu od bludi, / Da svete ljubavi i pravdenih ćudi: / Zato joj posudi da tko ju ugleda, / Svak joj se počudi i za njom pogleda. (M. MARULIĆ, 1970, 72)

14 N. KOLUMBIĆ, 2005.

15 D. FALIŠEVAC, 1997.

16 M. SOLAR, 2011, 228-229.

17 Oloferne nju kad prid sobom ugleda, / u ljubavi zašad, srce mu uspreda; / slaja mu bi meda, da gorkost će žerat, / studeniji leda kada bude ležat. / Kon sebe ju pojat hiti za trpezom / I niže njeje stat zapovidi knezom; / Njoj reče: 'Obezom jesi me obezala, / jer hrlim / potezom dojti si hajala. / Tim si dostojala da pri mni milosti, / ku želiš imala budeš u radosti.' (M. MARULIĆ, 1970, 82) 
vjeruje u Božje naume te odlučuje učiniti nešto kako bi uz Njegovu pomoć spasila svoj narod. ${ }^{18}$

Juditina hrabrost uvjetovana je ljubavlju prema Bogu i ufanjem u spas. Ne traži nikoga za pomoć, a jedino što traži je molitva Bogu. Judita je tako postala simbol nade, hrabrosti i pobožnosti, koja je uz Božju pomoć spasila narod od neprijatelja. Njezina ljepota i vjera bile su dovoljne da cijelu neprijateljsku vojsku zadivi i uvjeri ih u svoje dobre namjere. Renesansnu pripadnost djela potvrđuju uspjeli prikazi psihičkih stanja likova, opisi prirodnih pojava, krajolika, odjeće itd. ${ }^{19} \mathrm{U}$ pjesničkoj obradbi pripovijesti o hrabroj starozavjetnoj udovici može se iščitati politička alegorija s porukom: prijetećoj turskoj sili moguće je oduprijeti se osobnim junaštvom i vjerom u Boga. ${ }^{20}$

\subsection{Suzana}

Nešto kraći Marulićev spjev Suzana nosi također obilježja pjesnikove poetike, ali u njemu on ipak ne dostiže kvalitete Judite. Sama tema Suzane nije toliko veličanstvena i svojim osnovnim sukobima nije asocirala na najaktualnije prilike u domovini. Marulićevim tečnim jezikom ovaj spjev opet načima biblijsku temu o poštenoj Židovki koju su za vrijeme muževljeve odsutnosti napastovala u vrtu dva starca, ucjenjujući je, ako ne udovolji njihovim strastima, da će je oklevetati kako su je zatekli u preljubu. Nakon što ih je odbila, oni su izvršili svoju prijetnju. Kad je već bila osuđena na smrt, javlja se dječak Danijel (poznati biblijski prorok) i spašava Suzanu. Svojom tematikom i porukom ovaj spjev se ne izdvaja od ostalih Marulićevih religioznih moralno-didaktičkih pjesama. ${ }^{21}$ Biblijsku pripovijest Marulić komponira dvodijelno, u skladu s renesansnom simetrijom. Uz slavniju Juditu, Suzana je postala drugom renesansnom heroinom biblijske provenijencije. S nešto slobodnijim zahvatom, Marulić je pasivnu žrtvu pretvorio u moralnu junakinju, primjer kršćanske uzornosti. Kao što se u Juditi opisuje njezina herojska ljepota, tako se i u Suzani opisuje Suzanina ljepota vjernosti, postojanosti, nedužnosti. Njezina tjelesna ljepota i moralna ispravnost

18 Ko rič izusteći Ozija reče svim, / da grad da protivnim peti dan i petu noć, / ako nam protiv njim ne pošalje Bog pomoć? / Tko ste, da ćete moć božju iskusiti, / Ter svim vekšu nemoć, vekši gnjiv naditi? / Jer se rasrditi, hoće tom ričju Bog, / Pri ner se smiliti, ni dat nam odlog. / Vele dvigoste rog, roke teke upram / K Bogu, ko je svemog, da milost svu da nam, / Ter da tad pride sam pomoć puku semu, / Ka da je drago vam, ne kad je god njemu! / Milostan je u svemu, prošćen'je prosimo / Od togaj tere mu duše ponizimo. (M. MARULIĆ, 1970, 68)

9 M. TOMASOVIĆ, 1989, 1994, 2000.

20 M. SOLAR, 2011, 228-229.

$21 \quad$ N. KOLUMBIĆ, 2005. 
glavni je uzročnik i pokretač radnje..$^{22}$ Moralna i pobožna Suzana odbija starce jer ne želi počiniti grijeh pred Bogom. Ona također, kao i Judita, vjeruje u Božju ljubav i volju i njegove naume te mu se obraća kada je optužena na smrt. ${ }^{23}$

I Suzana i Judita štite izraelsku zajednicu: Judita ljepotu rabi djelatno - kao oružje kojim dobiva bitku za svoj narod, a pasivna Suzana štiti moralni sustav zajednice činom odbijanja pohotna grijeha. Marulićev kršćanski humanizam posjeduje određeni ton srednjovjekovne retorike u sekvencama teksta u kojima ženu ističe i kao biće grijeha, a ne samo biće vrline. Priča u Suzani ima drugačiju funkciju nego u Juditi: događaj je u službi moralističkog apela upućenog čitatelju, a može se usporediti s funkcijom exempla u okviru crkvenih propovijedi, gdje je priča podloga za razvoj teme. Sam lik naslovne junakinje oblikovan je simetrično i harmonično, kao lik koji krasi tjelesna i moralna ljepota. ${ }^{24}$

\subsection{Suzana cista}

Mavro Vetranović je izvrsno obrazovani svećenik i pjesnik, te pripadnik tradicionalno intelektualnog crkvena reda $\mathrm{a}^{25} \mathrm{i}$ kao takav dobar je poznavatelj klasike i Biblije, Dantea i Petrarce. Postao je plodan pisac dramskih i epskih tekstova, ali prije svega on je osebujan i izvoran pjesnik. Najveći dio njegove lirike su pobožne pjesme, u kojima donekle podsjeća na Marulića svojim didaktičkim i moralističkim tonom. Ipak, on se više približava tonu pravog osjećajnog lirizma. Vetranović je pisao i tri pobožna prikazanja: Uskrsnuće Isukrstovo, Suzanu čistu i Posvetilište Abramovo. Kod Vetranovića religiozne pobude mjestimice prerastaju u misaone preokupacije šireg zahvata preko kojih pjesnik ne samo problematizira udes čovjekov u dolini suza nego i svoju individualnu perspektivu.

Suzana čista pripada drugomu razdoblju autorova stvaralaštva, najvećim dijelom usmjerenomu Bogu i Božjoj ljubavi (u kojemu nastaje ukupno pet drama

22 Svak joj se čuđaše, govore: krasnije / Od nje da ne znaše. Hći biše Helkije. / Bile biše šije, a crnih očiju, / Glavice milije ner ti reć umiju. / Obrvi ter viju, nad kimi staše val, / Ako reć smiju, Bog biše upisal. / Tko bi nadaleč stal, rekal bi: rumen cvit / Od ust je nje procval, ali ružice list." (M. MARULIĆ, 1970, 108)

${ }^{23}$ „Ona ja vapiti: 'O svemogući Bože! / Prid kim se sakriti ništore ne može, / s nebeske ti lože otajstva sva vidiš, / i sudiš, tko može reć da ča ne vidiš? / Svaka ti prividiš, svaka t'su otvorena, / svaka razuvidiš pri neg su stvorena. / Ti znaš potvorena da sam ča u mni ni, / Lažno su smišljena svidočstva pram meni. / Pravedan si Bože ti, ne htij me ostaviti.' (M. MARULIĆ, 1970, 116)

\footnotetext{
4 D. MRDEŽA ANTONINA, 2008, 838-839.

25 A. PAVEŠKOVIĆ, 2000, 181.
} 
s temama iz Staroga i Novoga zavjeta). Dramatizacija je starozavjetne biblijske legende o starcima, Židovima Izaku i Ilijakinu, koji pokušavaju zavesti čistu Suzanu. Suzana na poticaj vjere - Boga želi dostići pravdu u svrhu oslobođenja od optužbe. ${ }^{26}$ Svojom je zgusnutom strukturom i gotovo psihološkim ustrojem dramskih osoba te smanjenjem didaktičnosti, pobožnosti i utilitarnosti u žanrovskome smislu više biblijska drama ili drama pravednosti nego tipično prikazanje. ${ }^{27}$ Suzana je opisana kao petrarkistička ljepotica zbog čije ljepote dva stara muškarca ne mogu spavati, o čijoj ljepoti neprestano razmišljaju i zbog čije ljepote vrijedi umrijeti. ${ }^{28}$ Kao i kod Marulićeve Suzane i Vetranovićeva Suzana štiti izraelsku zajednicu, ona na pasivan način odbijanjem bluda štiti njihove moralne osobine. Iznad svega stavlja svoju čast te vjeru i ljubav prema Bogu, ${ }^{29}$ koja najviše dolazi do izražaja u trenutku kada osuđena na smrt zaziva Boga. Vetranović se u ovom djelu više od Marulića udaljava od Biblije. Čitava se rasprava vodi kao pred dubrovačkim sudištem i propitkuje pitanje pravednosti u procesu suđenja, s posebnim osjećajem za status žene koju se lako moglo oklevetati. $^{30}$

\subsection{Draža je od zlata}

Sva je poezija Džore Držića nastala u 15. stoljeću. Njegov kanconijer sastoji se gotovo isključivo od ljubavnih pjesama. Poslije uvodne pjesme u kojoj se, neočekivano obuzet ljubavlju, s nostalgijom sjeća prošlog spokojnog života, pjeva o gospoji i njezinoj ljepoti, o svojoj čežnji i tuzi zbog neuzvraćene ljubavi, ali nema izrazito naglašenih faza udvaranja. U Držićevim pjesmama prevladava osjećaj žaljenja zbog nemilosti gospoje pa je tuženje osnovna intonacija

26 A. CAR-MIHEC, 1998, 123-130.

27 M. MUHOBERAC, 2008, 839.

28 Er kada Suzana mimo me tuj minu, / mnjah zraka sunčana svieh strana da sinu, / taj ures liepi dostojan svoj slavi / sasma me zasliepi jadovnom ljubavi, / da u boga smrt prosim, / da me smrt posvoji / za ljubav ku nosim Suzani gospoji. (M. VETRANOVIĆ, 1872, 346)

A to je vas uzrok Suzane ljepota, / da se prie skrati rok od moga života. / Za to me skončava lipos od Suzane / I meni zadava bez lieka te rane. (M. VETRANOVIĆ, 1872, 349)

${ }_{29}$ Er da mi sve date imanje i blago, / prie bih puknula na poli u saj čas; / $i$ živa sva u / prah prie bih se stvorila / neg li bih boži strah i viru pobila. / Znate li kolik trud u vieke / dobiva, / bezredno ženski blud s prikorom ko uživa? / Znate li, višnji gnjiv i srdžba od boga, / toj djelo tko je kriv, da znobi svakoga?" (M. VETRANOVIĆ, 1872, 356)

"Za to mi jes bolje, i prie obiru / da mi se prikolje i prava umiru, / neg z bogom u svadi živa bit' na saj svit, / da moj duh nasladi, kad budem ja umrit'. (M. VETRANOVIĆ, 1872, 358)

30 M. FRANIČEVIĆ et al., 1974. 
kanconijera. Njegova je gospođa draža od zlata i lipša ner prolitje. Epiteti i poređenja zvuče neposredno i epički. On se naivno, ali ipak uvjerljivo obraća svojoj simboličkoj i zato možda stvarnijoj vili. ${ }^{31}$ Držićevo stvaranje nastalo je prema uzoru na Petrarcu. Kod nas je petrarkizam bio glavni model renesansnog stvaranja, veoma dugotrajan i raširen. Oponašanje Petrarce je posredovano $i z$ druge ruke preko talijanskih sljedbenika njegova Kanconijera $\mathrm{i}$ izravno, tj. orijentirano, prema ugledanju na samog pjesnika. I našim je pjesnicima anđeoska ljepota gospoje od Boga poslana kao dokaz da ima raja. Oni opisuju gospoju s dva zlatna prama na čelu, slatkim govorom i anđeoskim hodom i pjevanjem. ${ }^{32}$ Draža je od zlata, lipša ner prolitje Držićeva je petrarkistička pjesma u kojoj, očaran svojom gospojom, uspoređuje njezinu ljepotu s proljećem, vilama, anđelima, govori kako njegova gospođa ima rajsko lice. ${ }^{33}$ Sve petrarkističke gospoje velika su inspiracija pjesnicima renesanse. Druženje s gospođama bila je privilegija i velika čast pa čak i smisao postojanja. Držić opisuje svoju gospoju kao nadnaravnu ljepotu, nešto vrijedno življenja, darom od Boga. Petrarkističke gospoje uvelike se razlikuju od biblijskih žena, međutim nisu od ništa manje važnosti. Biblijske žene pojam su hrabrosti i pobožnosti, dok su petrarkističke žene simbol ljepote i pjesničke inspiracije. Dok je Judita žena koja spašava svoj narod, žena koja svojim rukama ubija muškarca, petrarkističke žene su žene koje svojom hladnoćom i nedohvatnošću ubijaju muškarce. One svojim neuzvraćanjem ljubavi čine ono što je Judita napravila Holofernu. Iz toga se vidi koliko je bitan položaj petrarkističkih žena u renesansnoj književnosti. Nadalje, Držić opisuje svaki detalj gospojinog lica, kao znak neizmjerne 1jepote. ${ }^{34}$ Držićev je zaljubljenik zaokupljen vlastitim emocionalnim životom u kojem prevladava iskustvo neuzvraćene ljubavi, krotko podnosi žensku hladnoću, a njegova tužba zbog ljubavne boli prerasta u uvjerenje o sudbinskoj predodređenosti ljubavne patnje. Pohvala gospoje često se povezuje s doživljajem ljubavi kao nesvladive kozmičke sile.

31 M. FRANIČEVIĆ et al., 1974.

32 M. KOMBOL - S. PROSPEROV NOVAK, 1996.

33 Draža je od zlata, lipša ner prolitje, / po poljih kad cvata razliko jur cvitje. / Ljubav ju s nebesi i narav s zvizdami / najlipše uresi meu svim vilami. / Ima rusi kosi jakno zlate žice, / hladak ih uznosi uz rajsko nje lice. (DŽ. DRŽIĆ, 1965, 15)

${ }^{34}$ Oh, crna dva vlasa, vrh oči uzvita, / lipa t'su ukrasa, tanko t'su povita! // Oči nje jak zvizde gore u svitlosti, / u njih su sve gizde i rajske liposti. // Tanci su nje usti rumena uresa, / slatku rič izusti jak romon s nebesa. // A vesel smih stvori, sramom bez priroka, / čis biser otvori, ni lipšsi s Istoka. // Grlo nje pribilo bistro se prozire, / prozre se jak vrilo gdi čisto izvire. (DŽ. DRŽIĆ, 1965, 15) 
U nekim pjesmama žensku ljepotu prikazuje kao objavu te idealizirana gospoja dobiva ulogu posrednice između kršćanske onostranosti i muškarca. Osim petrarkizma, važnu ulogu ima srednjovjekovna semantika dvorske ljubavi, sa svojom koncepcijom pravednosti u ljubavi, odnosno koncepcijom amorozne službe i traženja naknade. Lirski subjekt obraća se gospoji uz nazive kao što su vila, gospoja i divica ili figurativne izraze kao što su sunačce, biseru, ružice. ${ }^{35}$ Žena je, u Držićevim pjesmama, naizgled aktivna, pokretač i uzročnik ljuvene boljezni, a ne samo odbijatelj muškarčevih ponuda. ${ }^{36}$

\subsection{Blaženi čas i hip}

Šš̌ko Menčetić smatra se tipičnim predstavnikom hrvatske trubadurskopetrarkističke poezije. On se, za razliku od Držića drži i kodificiranog stupnjevanja. On prolazi kroz sve konvencijom utvrđene faze, prikazujući prvo stidljivog obožavatelja koji se svojoj gospođi divi izdaleka, a zatim očita zaljubljenika koji javno i bez uvijanja slavi njezinu ljepotu i čari, neuslišana poklonika koji tuguje tražeći od nje utjehu i ljubavnika kojemu je gospođa otkrila znakove svoje naklonosti i koji će uskoro osjetiti sreću u njezinu krilu, da bi na kraju postao obraćenik koji prezire taštinu ovozemaljske ljubavi i okreće se Bogu kajući se za ljuveni blud. ${ }^{37}$ Po uzoru na Petrarcu, Menčetić je elaborirao zamašan ljubavni kanconijer sa svim tipičnim gradacijama, što baš nije čest slučaj kod drugih petrarkista. Njegova zbirka ima jednak broj pjesama koliko i Petrarkina, a posljednji joj je sastav također posvećen Bogorodici i ima paralelizama sa završnom kanconom iz Rasutih rima.$^{38}$ Prema petrarkističkom običaju, Menčetić opisuje onaj čas kad je prvi put ugledao gospoju i kad je bio od nje ushićen. Pojava gospođe i pojedinosti njezine ljepote u skladu su s petrarkističkim pojmovima o ljepoti. To je stasita pojava u bijelu ruhu i bijele kože, kojoj se niz bijelo grlo prosula plava kosa što će je gospođa oviti u svitak na glavi. Menčetić slavi onaj tren kada je ugledao svoju gospoju, sva mjesta i tren kada je čuo njezino ime. ${ }^{39}$ Nakon divljenja i zahvaljivanja trenutku kada je svoju gospođu upoznao, pjesnik se okreće zahvaljivanju svim trenutcima u kojima će patiti zbog neuzvraćene

\footnotetext{
T. BOGDAN, 2003.

T. BOGDAN, 2003.

M. FRANIČEVIĆ et al., 1974.

M. KOMBOL - S. PROSPEROV NOVAK, 1996.

39 Blaženi čas i hip, najprvo kad sam ja / vidil tvoj obraz lip, od koga slava sja, 7 Blažena sva mista, kada te gdi vidih, / dni, noći, godišta, koja te ja slidih. / Blažen čas i vrime, najprvo kada čuh / ljeposti tve ime, kojoj dah vas posluh. (Š. MENČETIĆ, 1968, 82)
} 
ljubavi, trenutcima u kojima će gubiti san zbog svoje gospođe. ${ }^{40}$ Petrarca u svom LXI. sonetu također prvo veliča dan, mjesec i godinu kada je svoju gospođu ugledao, a zatim blagoslivlja svoju patnju s kojom će ga ljubav izmučiti. I kod Menčetića i kod Petrarce, žena je razlog ushita, uzbuđenja, ali i ljubavne boli, razlog za koji se živi i umire, najveća ovozemaljska ljepota i dobrota. Međutim, lirski subjekti Menčetićevih pjesama znaju i žudjeti za skrovitim dijelovima ženskog tijela i senzualnim doživljajima. Kada okolnosti postanu nepovoljne za lirskog subjekta, on uz jadovanje, osvetoljubivo reagira prijetnjom ili ucjenom. Takva agresivnost usmjerena je prema nezahvalnoj i hladnoj gospođi. ${ }^{41}$ Držić i Menčetić naši su najuspješniji petrarkistički pjesnici. Oni gospojinu ljepotu opisuju kao ljepotu veću nego ljepotu najslavnijih žena u povijesti; pred njom pjesnik zamire ne nalazeći riječi, za njom uzdiše po danu, a blizu je smrti po noći. Temeljna je slabost te poezije konvencionalnost i nedostatak osobnog tona, premda u njoj katkada ima dražesti u pojedinim kraćim pjesmama.

\subsection{Robinja}

Kao gotovo svi renesansni pjesnici i Hanibal Lucić je ostavio malu zbirku petrarkističke lirike Pisni ljuvene. Ta zbirka ostatak je prijašnjeg zbornika, a pokazuje da je Lucić čitao neke ugledne talijanske pjesnike onog vremena, poput Pietra Bemba i Lodovica Ariosta.

Ta zbirka se odlikuje jasnijim jezikom od drugih tadašnjih zbirki, a osim toga u njoj je pjesma Jur nijedna na svit vila, koja je proglašena najljepšom pjesmom naše starije lirike. Pjesma je opis gospojine ljepote, kakav se obično nalazi u tadašnjim petrarkističkim zbirkama. ${ }^{42}$ No, posebno mjesto u njegovom opusu zauzima drama u tri čina Robinja. Nastala u istoj petrarkističko-leutaškoj atmosferi i inspiraciji, ona ipak donosi nove elemente. Svoj postanak zahvaljuje djelomično i narodnoj poeziji: iz nje u tu prvu hrvatsku dramu iz suvremene povijesti ulazi i unuk bana Derenčina i kći Vlaska Majera Podmanickog, koja je postala robinja, a zatim otkupom žena mladoga Derenčina. Robinja u duhu ondašnjih pokladnih igara završava pirovanjem. Međutim, ona je psihološki

40 Blažene boljezni, ke patih noć i dan / cić tvoje ljubezni, za koju gubljah san. / Blaženi jad $i$ vaj, ki stvorih dosade / želeći obraz taj sve moje dni mlade. / Blaženo vapinje, kad ime tve zovih, / i gorko trpinje, u željah kad plovih. / Blažen trak od uze ljuvene u kojoj / stvorih plač i suze želeći da sam tvoj, / Blažena ljepos tva, blažena tva mlados, / pokli se meni sva darova za rados. (Š. MENČETIĆ, 1968, 82)

41 T. BOGDAN, 2003.

42 M. KOMBOL - S. PROSPEROV NOVAK, 1996. 
složenija od dotadašnje crkvene drame i dana s više nijansiranja. Mladi Derenčin, kojega djevojka nije odmah prepoznala, pokušava ispitati njezina osjećanja. Robinja se kreće između priproste naivnosti i priproste osjećajnosti što je odaju njezini dijalozi s Derenčinom. ${ }^{43}$ U Robinji se ne može govoriti o jednostavnom prenošenju često isticanih faza trubadurskog opisivanja ljubavi, ali je sigurno da se i te faze javljaju određenim prirodnim redom. Više od svih udvarača Robinju oblijeće Derenčin, dakle njegovo se prvo ljubavno očitovanje zbilo prije otmice te realnim vremenskim slijedom Robinja odbija Derenčinova udvaranja iako ga je potajice voljela. Ta njezina oholija bila je i razlog za nesreću koju je doživjela kao kaznu. ${ }^{44}$ Robinja plače nad svojom sudbinom, zbog toga što je oteta, a zatim i zbog očeve smrti. ${ }^{45}$ Stvarajući dramu na osnovi produbljenih ljubavnih odnosa Lucić ujedno afirmira i misao o slobodnoj ljudskoj individualnosti, koja se u njegovu djelu konkretizira ljubavlju na temelju slobodnog odabira. Tu se radi o odjeku novog vremena kada se brak počeo demokratizirati sklapanjem ugovora u kojemu u ljubavni život ravnopravno s muškarcem ulazi i slobodna djevojka. Upravo zato je Lucić posvetio gotovo čitav drugi čin preispitivanju vjernosti kada Robinja otkriva svoju ljubav prema Derenčinu koju je prije krila iz svoje oholosti. ${ }^{46}$ Derenčin se odlučio na kupnju Robinje već na samom početku, čak i prije razgovora s njom. Na taj se potez odlučio već u razgovoru s gusarom. U njihovom razgovoru doznaje se još jedna stvar bitna za Robinju, pa tako i za Derenčina, a to je podatak da je Robinja nevina. Robinjina nevinost Derenčinu je bila znak njezine ljubavi i vjernosti. Sve probleme, Lucić je sveo na psihološku stranu, na ispitivanje djevojčine vjernosti ili ljubavi ili barem simpatije prema Derenčinu. ${ }^{47}$

43 M. FRANIČEVIĆ et al., 1974.

44 N. KOLUMBIĆ, 2005.

45 Vaj meni, ni li grih (gledajte cić Boga) / Da se tač izmorih mlajahna neboga, / Upala u ruke gusarom prihudim, / Ovako sve muke podnoseć da trudim? / Mogu li pokore na svitu ke ine / Najti se i gore tuge i gorčine / Neg ove ke tope brižnu me i dave, / Pogruziv od stope tja deri do glave? / Meni gorke noći, meni su gorci dni, / Odnikud pomoći bolizni mojoj ni. // A neć se ozriti na mene za sobom / Kâ želim umriti, kâ teku za tobom. / Biše u veselju i mene skončati, / A ne me dreselju i tugam podati, / A ne me na ovoj dohranit života / Da mi si ti pokoj, a život tegota. (H. LUCIĆ, 1968, 72)

46 Zatoj što obitaš doma me dopratit, / Dušu ako pitaš, dušu t'ću ne kratit. / A kako da neću na tu stvar pristati / Od ke milost veću ne umim pitati? / Meni bo jest mniti: koja bi ne rada / Derenčinu biti ljubovca i lada, / Ta bi se odvargla sve časti, sve slave, / I kralju navargla i caru zabave. / Znaj, se ponosila nisam ja od njega / Neg ga li nosila srid sarca mojega. / Ako li do sada nî mu se skazalo / Od mene nikada ljubavi nimalo, / Radi oholije (viruj mi) toj ne bi, / Kako se li mnije, targovče, sad tebi. (H. LUCIĆ, 1968, 82)

47 N. KOLUMBIĆ, 2005. 
Ova se drama može okarakterizirati kao drama osvajanja djevojčina srca ili drama otklanjanja nesporazuma. Ti nesporazumi nisu slučajno nastali u drami, već u pretpovijesti njihove ljubavne priče kada Robinja sputana dvorskom etiketom o ponašanju u ljubavi ne može slobodno Derenčinu otkriti svoje osjećaje, što on tumači kao znak njezine hladnoće i oholosti. ${ }^{48}$ Robinja je zapravo inverzija petrarkističke situacije. Takva interpretacija razaznaje dva ključna trenutka u ovoj drami: Robinja je kažnjena zbog svoje hladnoće te je izuzetno važna uloga njezinog djevičanstva i opasnosti tuđeg vlasništva nad njim. ${ }^{49}$

\subsection{Jeđupka}

Jeđupka Mikše Pelegrinovića posve je originalno i majstorski napisano djelo. Ona je spoj šaljive pokladne maskerate s prigušenim elementima ljubavne poezije. ${ }^{50}$ Maskerate su bile brojne u drugoj polovici 16. stoljeća u Firenzi i imale su podosta pučkog karaktera. Čar maskerata zbog njihova prpošna tona $\mathrm{i}$ veće mogućnosti odstupanja od manire bio je privlačan mnogim pjesnicima, kojima su one bile odušak od kanconijerske lirike. Kod nas su maskerate uživale znatnu popularnost $\mathrm{i}$ bile su javno izvođene. ${ }^{51} \mathrm{U}$ ovoj maskerati izvrsno je pogođena psiha Ciganke, ali Ciganke iz hrvatskih krajeva. ${ }^{52} \mathrm{U}$ uvodnoj pjesmi Ciganka, zapravo maskirani pjesnik pozdravlja prisutne gospođe i priča im o nevoljama i zloj sudbini svoga plemena, o gubitku trojice sinova, a zatim se obraća izabranoj gospođi i obećava joj sreću moleći dar od nje. U Sreći prvoj, koja odgovara pjesmi Prvoj gospođi iz venecijanskog izdanja, Ciganka gospođi bez djece proriče da će imati dva sina, ugledna i sretna, ali joj u duhu karnevalske igre preporučuje da vrijeme ne troši uzalud bez trajanja ljuvenog. ${ }^{53}$ Drugu gospođu Ciganka upozorava na nevjernog muža čije ljubavnice od njega samo izvlače novac. Pelegrinović bez ikakvog obzira, vrlo otvoreno i samouvjereno stavlja ženu u ravnopravan odnos prema



53 Dvi ćeš rodit muške glave / mnoge sriće, mnoge česti, / od kojih će ime resti / po svem sviti vječne slave. // Prvi će imit tuj besidu / prid gospodom i to ime, / da će biti blago š njime / kumu, drugu i susidu. / Drugoga ćeš vidit banom / od jezika od svih naju, / gdi stoluje na Dunaju / po milosti zgoru danom. // Da ovo t'svjeta službenoga, / ki ću t'dati na rastanci: / ne čin' da ti prođu danci / bez trajanja ljuvenoga; // er gospoja bez ljubavi / što je ino, boga cića, // ner ugasla jedna svića, / ili t'suh panj u dubravi? (M. PELEGRINOVIĆ, 1968, 111) 
muškarcu. ${ }^{54}$ Njegova Ciganka savjetuje ženi koju muž vara i prihvata tuje lade neka mu uzvrati. ${ }^{55}$ Takav odnos prema ženi rezultat je nove društvene svijesti, kada su pucali okovi feudalnog dogmatskog mišljenja. Umjesto podređenog položaja u društvu sada ona dobiva potpunu ravnopravnost, što je u skladu s afirmacijom ljudskih vrijednosti. Posebno mjestu u ovoj maskerati zauzimaju stihovi Šestoj gospođi iz dubrovačke varijante u kojemu se pjesnik potpuno otkrio. Skrivao se pod maskom Ciganke, zaljubljen u određenu gospođu. Iskoristio je prigodu i otkrio sve što osjeća iznenađujuće toplo i originalno. Pri kraju pjesme njegove emocije su ga toliko ponijele da se na Ciganku gotovo i zaboravi. To su stihovi oduševljenog obožavatelja koji voli beskrajno, iskreno i idealno, sav ponesen i uzbuđen. Njegova ljubavna izjava izrečena je nenametljivo i postupno, prvo hvaleći gospođu i laskajući joj, a zatim upozoravajući na jedini njezin nedostatak: ne uzvraća ljubav onome koji za njom uzdiše. Ciganka uvjerava gospođu kako je zaista iskreno voljena pa bi trebala ljubav i uzvratiti. Na kraju se pjesnik otkriva pa prijelazom od zahtjeva za materijalnim darom, u vatri zanosa prelazi na govor srca i ljubavi moleći sladak pogled..$^{56}$ Osobito je hvaljeno dočaravanje Cigankine psihe, postignuto oblikovanjem njezina govora. ${ }^{57}$ Ciganka je u prvom redu najbolje prikazala i otkrila sebe. Nakon duga i zamorna života, a ne izgubivši pritom nimalo svoje svježine i duha, Ciganka se kreće od jedne do druge gospođe i priča, savjetuje, filozofira i uvjerava. Nenametljivo, ali oprezno Ciganka računa na razne tipove susreta, a pritom dobro pazi što će i kako će reći. Ostajući izvan i iznad stereotipne vračare, ona će nekad diskretno i toplo, a nekad rječito i dvosmisleno pokazati o čemu sanjaju i za čim čeznu misao i srce sakriveni ispod maske i otrcanih haljina. ${ }^{58}$ Raznovrsnošću gospođa i sreća te izborom problema Ciganka otkriva čitavu galeriju likova jednog društva, lepezu bračnih slučajeva i odnosa, a pogotovo čitav zbir žena i djevojaka iz bogatijih slojeva. Svaka žena okarakterizirana je na svoj način, sa svojim problemima, udvaračima, muževima, odnosno s tipičnim problemima tadašnjice, ali i

54 N. KOLUMBIĆ, 2005.

55 Dostoji li tvoja mladost, / tvoja vera, tva lipota / tuj gorčinu od života? / nu procini tvoja radost! // ter viđ, er se ne povraća / naša mlados ni nje slave, / a huda je žena, prave, / s vrhom zajma ka ne vraća. (M. PELEGRINOVIĆ, 1968, 113)

56 Ako li ti nije godi / ništa toga meni dati, / nu mi daj to ne zakrati, / što t'za pinez ne dohodi: // daj mi na ov česmen danak / sladak pogled, slatku ričcu, / il'što je slaje u tvom ličcu / negli trudnu zorni sanak. (M. PELEGRINOVIĆ, 1968, 127)

57 T. BOGDAN, 2003.

58 R. BOGIŠIĆ, 2000. 
sadašnjice. Preokret u ovom djelu čini odnos prema ženama, tj. uvažavanje spola i njihove ravnopravnosti. Uz Lucićevu Robinju gdje se također uvažava individualni izbor stupanja u brak slobodnog muškarca i slobodne ravnopravne žene i Pelegrinović je slobodoumno indicirao na varanje muškarca od strane žene, odnosno na vraćanje istom mjerom. Položaj žena u književnim djelima, kao i stvarnosti tadašnjice doveden je u pitanje ravnopravnosti i poboljšanja njihovog položaja u društvu i ljubavnim odnosima. ${ }^{59}$

\subsection{Dundo Maroje}

Najvažniji rod renesanse u hrvatskoj književnosti bila je nesumnjivo drama, osobito razvijena oko polovine 16. stoljeća. Dramske predstave nisu bile novost u primorskim gradovima jer su se u njima prikazivale duhovne drame. Iako se duhovna drama još i kasnije pojavljuje, ona već od druge polovine 16. stoljeća gubi svoju važnost, jer su se u to doba razvijale svjetovne drame. To su u prvom redu pastirska igra i komedija.

Najvažniji pisac pastirskih igara i komedija, a i najdarovitiji pisac svog vremena je Marin Držić. ${ }^{60}$ Dundo Maroje pripada ne samo najnadahnutijem nego i najzrelijem Držiću. U tom djelu, koje po svemu prelazi okvire plautovske, eruditne komedije, Držić daje široku panoramu ondašnjeg dubrovačkog društva: ljudi nazbilj i ljudi nahvao te onih koji su najčešće i jedno i drugo, ali i nešto što je mnogo više - umjetničko djelo u kojemu je naš komediografski izraz dostigao ne samo najviši domet nego i vrhunsku zrelost. Držić otkriva likove koji prije na taj način nisu bili otkriveni, ondašnji svijet koji je postao i svagdašnji. ${ }^{11}$ Iako komedijom dominiraju muški likovi, važno je istaknuti ulogu ženskih likova. Moguće je da je Laurin lik izveden iz jedne od stvarnih rimskih prostitutki, kurtizane koje se upuštaju u odnos s mladićima u namjeri da od njih izmame novac. ${ }^{62}$ Sve najvažnije fabulativne linije vodile su ovoj kurtizani. O Lauri se mnogo doznaje iz Pometovih riječi kada se ukazuje na njezinu promjenu identiteta. ${ }^{63} \mathrm{Da}$ je Laura lukava i prepredena govori

\footnotetext{
N. KOLUMBIĆ, 2005.

60 M. KOMBOL - S. PROSPEROV NOVAK, 1996.

${ }_{61}$ M. FRANIČEVIĆ et al., 1974.

62 A. PROLIĆ KRAGIĆ, 2009, 430.
}

${ }^{63}$ Signora Laura, - znam kad se i Manda zvaše u Kotoru, - non tanta superbia! Sad mi toškano govoriš, a naši smo, ili hoćemo ili nećemo. Neće vazda jednako brijeme bit: za slatkijem ljetom dođe i gorka zima; i ti cvijet od ljeposti, kojom se oholiš, mogao bi i kozomor još potlačit. Vidjeli smo i druzijeh sinjora u Rimu, velicijeh kako i ti, koje, koliko su na višemu bile, toliko su na bašije pali. (M. DRŽIĆ, 1962, 205) 
činjenica da fingira ljubav prema Mari samo da izvuče što više zlata i dragulja. To primjećuje i Popiva, prigovarajući Pometu ${ }^{64}$. Uz status istaknute rimske kurtizane potrebno je povezati njezinu tjelesnu ljepotu, svojevrstan društveni ugled i visoku cijenu njezine milosti koja ovoj bogatoj gospođi omogućuje luksuzan život u odori od svile i u kući punoj srebra $i$ zlata. ${ }^{65}$ Iz njezina dijaloga sa Sadijem saznaje se kako joj je Maro sve to bogatstvo poklonio u kratko vrijeme. ${ }^{66}$ Lauri nije bitna Marina ljubav, ona ljubav mjeri u kupljenom nakitu, ogrlicama i haljinama, smatra da je našla mladića dostojna njezine ljubavi zbog bogatstva koje joj može pružiti, ne znajući odakle dolazi to bogatstvo i koliko će trajati. Njezinu milost moguće je kupiti jedino dukatima, no nije svjesna kako se bogatstvo i sreća mogu vrlo brzo preokrenuti. Ona je ohola kurtizana za čiju naklonost se bore Maro i Ugo Tudešak kojem će na kraju otići nakon što Maro ostane bez dukata. Ona pripada Držićevim ljudima nahvao te zaslijepljena svojom pohlepnom prirodom ostaje bez 3000 dukata kojima je pristala jamčiti u Marino ime misleći da će ga kasnije moći još više iskoristiti. Zanimljivo je i njezino ime koje si je nadjenula došavši u Rim, koje je u suprotnosti s petrarkističkom idealnom ženom Laurom. Laurina sluškinja, vesela i živahna Petrunjela, veseli se svakom susretu svojih udvarača, Pometa i Popive. Ona koketira sa svim udvaračima, ali ih odbija služeći se folklornim pjesmama vješto se prilagođavajući novoj situaciji i govorniku. ${ }^{67}$ Po svojem jeziku, vještini repliciranja i pariranja muškim protagonistima nije profilirana kao žrtva patrijarhalne moći, već pokazuje da je u borbi spolova jednako jaka kao i njezini izazivači ${ }^{68}$ Unatoč dodirima svojih udvarača, ona ostavlja dojam čestite djevojke koja je, poput Laure, promijenila svoje ime dolaskom u Rim. Od svoje gospodarice preuzela je neke oblike ponašanja pa tako Marov sluga Popiva dio nakita daje njoj, što ona velikodušno prihvaća. Petrunjela je okarakterizirana kao materijalistički nastrojena osoba, ali ne prijetvorna i lažljiva kao Laura, već svoje stavove o materijalnim stvarima, kao i o muškoženskim odnosima izgovara javno bez skrivanja. Premda Lauru tretira kao dobru osobu zbog čega joj je vjerna sluga, Laura se prema njoj odnosi samo

${ }^{64}$ A Pomet Trpeza iza vrata gleda s svojijem Tudeškom, koji vinom hoće intertenjat prvu kortidžanu od Rima. S dukati dođite u sinjore Laure kako i mi! Neće sinjore ovake havijara ni vina, - dukata hoće, a vi ih ne imate. (M. DRŽIĆ, 1962, 208)

${ }_{65}$ A. PROLIĆ KRAGIĆ, 2009, 430.

${ }_{66}$ Moj Sadi, da znate što mi je sve kupio ima godinu dana, začudili biste se: možda za tri tisuće dukata nakita, ogrlica, haljina i drugih stvari. (M. DRŽIĆ, 1962, 236)

67 A. PROLIĆ KRAGIĆ, 2009, 430.

68 D. FALIŠEVAC, 2013. 
kao prema sluškinji. ${ }^{69}$ Odnos muško-ženskih likova u ovom djelu može se promatrati kao još jedan renesansni izraz. Komedija je prepuna petrarkističkih izljeva ljubavi. Žene, odnosno kurtizane i sluškinje promatrane su kao petrarkističke ljepotice kojima se pjeva, ljubi, govori se o njihovoj ljepoti te njihovoj milosti. Njihova ljubav najveće je dobro koju muškarci mogu uživati, zbog nje se živi i umire.

Međutim, razlika između Držićeve i Petrarkine Laure je u tome što je Petrarkina Laura čestita žena, kojoj se pjeva i za čiju ljubav se moli, ona je nedostižna i zbog njezine ljubavi se pati, dok je Držićeva Laura primjer dalmatinske kurtizane koja se od rimskih razlikuje po svojoj konzervativnosti, ali ipak nije čestita žena, njezina ljubav je dostupna ali samo iz materijalne koristi. Te dvije Laure spaja samo njihova ljepota, a Držić je samim davanjem imena Laura želio ukazati na njihovu suprotnost i na taj način dati komediji još veću dozu humora i ironije.

\subsection{Dubravka}

Ivan Gundulić ušao je u književnost mlad, a privukla ga je najprije drama koja je u to vrijeme upravo osvajala talijansku pozornicu. U šesnaestom stoljeću pored komedije vladala je pastirska igra, koja je sa svojim zbornim pjevanjem, pratnjom instrumenata i plesom sadržavala mnogo glazbenih elemenata.

Dubravka je pastirska drama u čijem su središtu radnje dvoje zaljubljenih, Miljenko i Dubravka. Njihovoj sreći stali su na put podmitljivi suci, koji Dubravku dosude starom i bogatom Grdanu umjesto Miljenku, ali kada Grdan i Dubravka stupe u hram boga ljubavi Lera, nastane trešnja, žrtva nije planula, a Lerov stup se krenuo znojiti. Međutim, kada je ušao Miljenko, sve se smirilo, plamen je buknuo, a Lerovo lice se razvedrilo. Na taj znak, svećenik je vjenčao najljepšu pastiricu s najljepšim pastirom. Iako je Gundulićeva Dubravka sagrađena na ljubavnom zapletu, težište drame je u rodoljubnoj tendenciji. Gundulić je proslavljanje dubrovačke slobode povezao sa samom radnjom drame. ${ }^{70}$ Dubravka je najljepša pastirica o čijoj ljepoti svi pričaju, a to se saznaje već iz prvog skazanja od Radmia. ${ }^{71}$ O Dubravkinom položaju doznaje se već u Ljubmirovim riječima, o ženidbenim običajima u kojima najljepša pastirica ide najljepšem

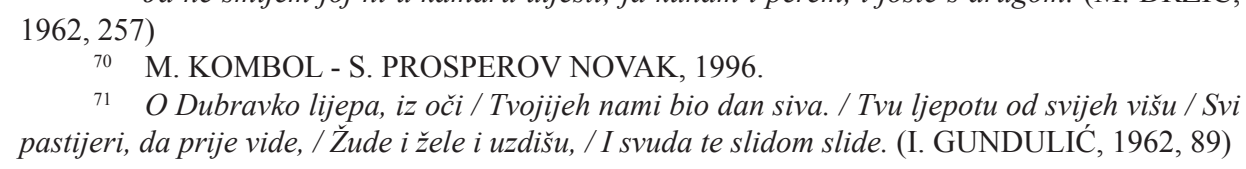

70 M. KOMBOL - S. PROSPEROV NOVAK, 1996.

${ }^{71}$ O Dubravko lijepa, iz oči / Tvojijeh nami bio dan siva. / Tvu ljepotu od svijeh višu / Svi pastijeri, da prije vide, / Žude i žele i uzdišu, / I svuda te slidom slide. (I. GUNDULIĆ, 1962, 89)

${ }^{69}$ Ja ne smijem joj ni u kamaru uljesti; ja kuham i perem, i jošte s drugom. (M. DRŽIĆ, 
pastiru. Dakle Dubravka, premda se može smatrati da je na kraju imala sreću i udala se za Miljenka koga je voljela, ipak nije imala slobodu izbora. Njezin život igra je sreće, u kojoj je, u ovom slučaju, ona pobijedila. Od same Dubravke ne doznaje se mnogo, njezin i Miljenkov lik ostao je pasivan u cijelom djelu. Tako je starica Pelinka savjetovala Miljenku da se Dubravki približi darovima, što on kao idealan pastir odbija, ističući kako se do ljepote ide čista srca, a ne pune kese. ${ }^{72}$ Baš kao i Miljenko, Dubravka je okarakterizirana kao idealna pastirica, ne samo zbog svoje ljepote već i dobrote. Upravo zbog njezine dobrote ni sam bog ljubavi Lero nije dopuštao njezinu udaju za staroga Grdana, nije dopuštao nesretnu ljubav toj savršenoj pastirici. Na kraju se ipak nešto doznaje i od same Dubravke, a to je njezina ljubav prema Miljenku. ${ }^{73}$ Skup pastira, na kraju pjeva himnu slobodi u čast Dubravkine slobode, i udaju za Miljenka, odnosno pastira kojeg voli.

Iako se lik Dubravke promatra kao nježni idealni ženski lik koji ovisi o sudbini boga Lera, ona ima sasvim drugo značenje. Njezin lik je alegoričan i trebao je u ono vrijeme predstavljati Dubrovnik. ${ }^{74}$ Dakle, cijela drama je alegorijski napisana, pa se i sama Dubravkina sloboda odnosi na slobodu Dubrovnika, odnosno njezinim likom Gundulić aludira na to da vlast treba ostati u rukama vlastele koja se pod svaku cijenu moraju izboriti za slobodu grada i da je to Božja volja i volja naroda.

\subsection{Suze sina razmetnoga}

Religiozna poema Suze sina razmetnoga osvjedočenje je o Gundulićevoj religioznosti što je vrhunac hrvatskoga književnog baroka. U toj poemi on je postigao punu mjeru svoje umjetnosti, koristeći se konvencionalnim žanrovskim baroknim odrednicama ugradivši u njihove okvire vlastiti doživljaj problema čovjekove egzistencije, problem odnosa između čovjeka i Boga, osobito tragičan osjećaj prolaznosti i posvemašnjeg besmisla. ${ }^{75}$

Suze sina razmetnoga obrađuju biblijsku parabolu iz Lukina Evanđelja o grešnom, razmetnom i zabludjelom sinu. Prema svoj strukturi građene su kao talijanski barokni plačevi. Suze sina razmetnoga, podijeljene u tri plača (Sagrješenje, Spoznanje i Skrušenje), slijede put čovjekova pročišćenja od

72 M. FRANIČEVIĆ et al., 1974.

73 O prislatko, o jedino, / Drago ufanje, željno meni! / O uresu moj ljuveni, / Noći moje sunce istino! // Ja sam ona ke lipotu / Vjerno ljubi, dvorno slavi, / O gizdava ma ljubavi, / O jedini moj životu! (I. GUMDULIĆ, 1962, 143)

74 M. SOLAR, 2011, 123.

75 B. PETRAČ, $1989,458-465$. 
spoznaje vlastite grešnosti, trenutnosti i konačnosti do prihvaćanja Božje milosti i predanja Božjem zagrljaju. Glavni grijeh ove poeme je bludnost, potaknuta predivnom ženom. U duhu baroka, krivica za grijeh pada na pleća žene, razbludne i varave, koju razmetni sin optužuje za svoje grijehe. ${ }^{76}$ Osim što okrivljuje ženu za svoju bludnost, što naziva ženu lažljivom, razmetni sin govori kako nema ni pred kim srama ni straha. ${ }^{77}$ Također, ukazuje na njezinu bludnost i prijevaru. ${ }^{78}$ Dok govori o ženinoj bludnosti, o njezinoj prijetvornosti i lažljivosti, razmetni sin otkriva razlog zbog kojega je počinio blud, ali i razlog zbog kojega je žena bludnica. O muškom tijelu se ne govori kao o potencijalnom izvoru grijeha, a ako i jest grešno, to je zbog toga što ga je na grijeh navela žena. ${ }^{79}$ Taj razlog je njezina ljepota pa razmetni sin opisuje ženu kao što su petrarkisti opisivali ženinu ljepotu. ${ }^{80}$ Nakon petrarkističkih izjava o ženinoj ljepoti, ona opet poprima ulogu bludnice, međutim ovaj put razmetni sin u potpunosti radi kontrast njezina lika pa ju opisuje kao staricu i rugobu. Žena je, dakle, opisana na tri različita načina: prvo kao bludnica, zatim kao petrarkistička ljepotica, a zatim kao ružna starica. Samim time, Gundulić daje sliku žene koja postaje grešnica ${ }^{81}$ Srednjovjekovna opsesija tijelom ostala je zabilježena u nizu tekstova u kojima se osuđivala sama pomisao na tjelesnost. Tjelesna ljepota žena istaknuta odjećom i nakitom predstavljala je prijetnju muškarcima, a zbog Evina grijeha često se uspoređivala sa zmijom. ${ }^{82}$ Razmetni sin govori kako ona ima otrovno srce te je optužena za sve loše stvari koje su mu se dogodile. ${ }^{83}$ Nadalje, žena je okarakterizirana kao

76 Da razmetni sin optužuje ženu za sve svoje grijehe saznaje se iz stihova: Ah, na ovo $l i$ bludnos tvoja / Dovela me, izdavnice, / Ka pod slikom od pokoja / Dvorne i blage ljubovnice / Na službu me tvu zapisa, / Dokli iz mene krv isisa? (I. GUNDULIĆ, 1962, 42)

77 Ka sred srca ne imaš svoga / Srama od ljudi, straha od Boga. (I. GUNDULIĆ, 1962, 42)

78 Unečistoj koga želji / Ne prigrli i ne primi? / Tvoji su bludni prijatelji / Vazda bili, ljeti i zimi, / I tuđini i mještani / S kim te ugađa trg pogani. (I. GUNDULIĆ, 1962, 43)

Ah, s kijeme se nijesi stala? / Tko ti bio nije sred krila? / Tko je taj koga nijes 'izdala, / Koga nijesi privarila. (I. GUNDULIĆ, 1962, 42)

79 M. TATARIN, 2010, 223-255.

80 Bijaše zlatni pram vrh čela / Za razbludu raspustila, / Svitlos draga i vesela. // Od koralja usti objavi / A od lira prsi svoje. / Govoraše nje gizdavi / Podsmijeh: 'Daj mi srce tvoje!'/ Veljaše opet: 'Daj ga meni!'/ Pogled slatki i ljuveni. (I. GUNDULIĆ, 1962, 43)

${ }^{81}$ A ona stara i skorjena / Priobrazila sliku biše, / Čim oblipi i namasti / Blijede kože suhor tmasti. // A ostriže s mrca vlase / I crvima ize iz usti, / Te ih iz groba stavi na se // Pepeo lica pogrešpana, / Suha, žuta i pjegava. (I. GUNDULIĆ, 1962, 45)

82 M. TATARIN, 2010, 223-255.

${ }^{83}$ Cvijetje u rukah, cvijetje svuda, / I ona u cvijetju zmija huda. // Medna je riječca, srce otrovno; / Oči ognjene, prsi od leda; / Ljubit kaže, mrzi skrovno; / Vijek ne želi, sveđ te gleda; / Jedno misli, drugo čini; / Vara, izdaje, laže i hini. (I. GUNDULIĆ, 1962, 45) 
bezdušno biće koje ljubav mjeri u poklonima i zlatu, kao zmija koja s njim jede i pije, koja se pretvara da mari za njega te kao biće koje je nezasitno materijalnim stvarima, odnosno kao pohlepno biće. ${ }^{84}$ U Spoznanju, sin razmetni opisuje ženu kao zavodnicu koja muškarce zavodi svojom kosom, a zatim ih ranjava i navodi na mnoga zla. ${ }^{85}$ Žena je naposljetku okarakterizirana kao iznimna ljepotica koja se protivi svojoj nutrini, koja je čista suprotnost. Iznutra, ona je prljava, tašta i bludna, žena izdajnica koja svakog muškarca prima u svoje okrilje.

U baroknim djelima, žene su često pokretači radnje, ali kao razvratnice i bludnice. Često su razlog svim lošim stvarima, uzrok muškarčeve boli i kajanja. Premda postoje idealizirani opisi ženine ljepote, ona su nezamjetna u odnosu na ostale opise koji govore o njezinoj ružnoći i iskvarenosti. Ona je u ovom djelu razlog svog zla sina razmetnoga, sve njegove boli i nesreće. Na kraju, aludiranjem na prolaznost ženine fizičke ljepote ostaju stihovi: Slavne gospođe $i$ kraljice, / Kih liposti još se hvale, / Zlatne kose, drago lice, / Ljuven pogled ke su imale, / Ah, viđ što su u ovo doba: / Malo praha udno groba! ${ }^{86}$

\subsection{Osman}

Epopeja se u baroku smatrala vrhuncem književnoga stvaranja. Tassov Oslobođeni Jeruzalem u 17. stoljeću našao je bezbroj epigona. Stoga nije ni čudo da je i Ivan Gundulić kanio prevesti Tassovo djelo želeći ga posvetiti poljskom kralju kao predstavniku kršćanske borbe protiv Turaka. ${ }^{87}$ Međutim, daljnji događaji odvratili su Gundulića od te ideje pa je on u svom Osmanu opjevao suvremene događaje.

Njegov spjev u 20 pjevanja počinje s odlukom mladog cara Osmana da krene na Istok po novu vojsku da obnovi staru tursku slavu. Sultan ne izvršava tu svoju namjeru odmah, već prvo šalje Ali-pašu u Varšavu da sklopi mir s Poljacima, a Kizlar-agu u balkanske pokrajine da kupi djevojke. U tim epizodama značajne su žene ratnice, koje se preobučene kao vitezovibore kopljem i mačem, a kao ljubavnice ipak ostaju prave žene. ${ }^{88}$ Takva je na kršćanskoj strani Poljakinja Krunoslava, koja

${ }^{84}$ Da su od zlata polja i gore, / Da sve rijeke zlatom teku, / Da je pučina zlatna more, / Da vas saj svijet zlatan reku: / Svim tijem ne bi stoti dio / Ženske želje napunio. (I. GUNDULIĆ, 1962, 52)

${ }^{85}$ Ti nevješte mladce vodiš / Mrtvijem pramom zavezane, / Pogledom ih ti gospodiš / I u srcu stvaraš rane; / Ti ih vodiš na zla svaka: / Oni hudi, ti si opaka. (I. GUNDULIĆ, 1962, 55)

86 I. GUNDULIĆ, 1962, 59. 2004.

87 O Marulićevoj, Gundulićevoj, Vetranovićevoj... predodžbi Turaka pogledati D. DUKIĆ, 88 M. KOMBOL - S. PROSPEROV NOVAK, 1996. 
čuvši da joj je vjerenik Korevski zarobljen u Carigradu polazi preobučena kao vitez u Carigrad da ga oslobodi, ali pri tom sama upadne u tamnicu. Na turskoj strani nalazi se Sokolica, koja se u bitci kod Hoćima pred objema vojskama našla u dvoboju s Krunoslavom. Uz Sokolicu i Krunoslavu važan lik u djelu je još i Sunčanica. Kći starca Ljubdraga otima Kazlar-aga za harem sultana Osmana te se tako uz Sunčanicu veže motiv robinje. Uz ove ženske likove valja spomenuti i Mustafinu majku koja ima posebnu ulogu, u potpunoj suprotnosti od prethodna tri lika. Ona, naime, ima ulogu žene vještice koja odskače svojom vanjštinom i nutrinom od ostalih žena u epu. Fikcionalni svijet hrabrih junakinja slijepa je ulica koja nema izlaza, koja živi usporedno sa svijetom povijesno relevantnih događaja, ali na taj svijet ne utječe, odnosno one ne mijenjaju partnerove povijesno važne odluke niti utječu na njihove pobjede i poraze. Junakinje u Osmanu nositeljice su romantično-viteškog svijeta koji ostaje zatvoren u sebe, ne djeluju niti na rat niti na mir. ${ }^{89}$ Sokolica je romantična ratnica u Osmanu podrijetlom iz dinastije Tatara koji su vladali Indijom..$^{90}$ Sokolica je zaljubljena u Osmana, ali unatoč tome bježi od njega jer smatra da je Osman ne želi kao ženu ravnopravnu njemu već kao robinju, a njoj je draža njezina sloboda od ljubavi. ${ }^{91}$ Da je hrabra i da je spremna umrijeti za Osmana vidi se iz sljedećih stihova u kojima je, neznajući tko se krije iza oklopa, spremna boriti se za Osmana: Od moje ćeš ruke umrijeti, / tko god ti si od bojnikâ. ${ }^{92}$ U nastavku njihova dvoboja saznaju se vrline Sokolice, ali i Krunoslave. U njihovu dvoboju, odnosno dvoboju dviju žena, zanimljiva je činjenica da su muškarci pasivni promatrači. Krunoslava je prikazana kao vita jela koju krasi zlatno oružje na kojemu ima znak ptice. Sokolica je bistra, hitra, ponosita i ohola, a baš kao i Krunoslava, i ona jaše na brzom i lijepom konju. Do trenutka u kojem im padaju kacige s glava i otkrivaju se njihovi identiteti, nitko nije ni slutio da se ispod svega nalaze dvije djevojke. I Sokolica i Krunoslava, obje jednako lijepe, zastupaju ravnopravno svaka svoju vojsku. U trenutku spoznaje cijela vojska ostala je bez daha od njihove ljepote. ${ }^{93}$ Sokolica je okarakterizirana ne samo kao blago žensko

D9. FALIŠEVAC, 1997.

90 M. KOMBOL - S. PROSPEROV NOVAK, 1996.

91 Ali i za njim Sokolica / i ne manjijem ognjem gori; / ljuven pogled s draga lica / i nje tvrdo srce otvori. / Gori, ali plame krije / gorke trpeć vik boljezni; / ljubi, ali još ne smije / objaviti sve ljuvezni. / Čezne mlada i neizmernu / sumnju ima da car i nju / ne bi uzeo ne za vernu / ljubi nego za robinju. (I. GUNDULIĆ, 1964, 51)

92 I. GUNDULIĆ, 1964, 61.

93 Zlato prosu, pram razveza, / zasjaše oči, svanu lice: / otkriše se dva viteza / dvije mlađahne djevojčice. / Jakno sunce iza oblaka / draže objavi svê svjetlosti, / iza oružja sviću taka I dva sunca ova od liposti. / Bez uzdaha ko ih gleda, / ter mu dano gorjet ne bi, / ili stvoren vas je od leda, / ili srca ne ima u sebi. (I. GUNDULIĆ, 1964, 64) 
biće zaljubljive naravi, već i kao hrabra i odlučna ratnica, koja uz svoju družinu nosi koplje, a očima, metaforički, drži strijele. Zlatne kose, sa sabljom i lukom, umjesto oklopa nosi cvijet. ${ }^{94}$ Kupanje Sokolice i njezinih bojnica je najglasovitiji prizor Osmana uopće. Ono ima važnu funkciju u doživljavanju ženske ljepote i tjelesnosti. Opis tog kupanja primjer je petrarkističkog opisivanja ženske ljepote u kojemu Gundulić spaja nespojivo (živim ognjem voda planu), čime je žensku ljepotu proširio na cijelu prirodu. ${ }^{95}$

Jednaka Sokolici, s druge strane, nalazi se Krunoslava. Ona nije posve izmišljena osoba jer se može dovesti u vezu s Katarinom, ženom Samuela Koreckog. U tvorbi njezinog lika Gundulić je imao pred očima sudbinu nesretne Katarine. Na glas o zatočenju Korevskog Krunoslava poziva na dvoboj Osmana, ali joj suparnica postaje Sokolica. Njezina ljubav prema zaručniku toliko je jaka da hrabro kreće u neprijateljski tabor kako bi ga pronašla i oslobodila. Ona je, kao i Sokolica, primjer žene ratnice, ali za razliku od Sokolice, njoj na prvom mjestu nije sloboda nego ljubav. Samim time vidi se kako su žene u Osmanu imale mogućnost slobodnog izbora i krojenja vlastite sudbine. Baš kako je Sokolica skrivala svoju ljubav prema Osmanu, tako je Krunoslava pošla za Korevskim u borbu. Čuvši da je zarobljen, njezino srce se slama, život joj ništa ne vrijedi bez njega. Tu pokazuje svoju slabost, ali već u sljedećem trenutku ona se izdiže iz svoje patnje, pokazujući koliko je psihički jaka i stabilna žena. ${ }^{96}$ Krunoslava je poznata ratnica, njezina slava proširila se na sve strane, o čemu svjedoče stihovi u kojima ju je paša odmah prepoznao. ${ }^{97} \mathrm{O}$ njezinoj vjernosti i čestitosti jasno

94 Glasovita Sokolica, / velikoga kći Mogora. / U nje družbi dvanaes ona / djevojčica bojnijeh ima, / i moguća i smiona / cijele vojske zateć njima. / Sve u rukah kopja nose, / a u očiju drže strijele; / vezi od zlata njih su kose / Kaciga joj resi teška / mješte vijenca zlate kosi; / štit zrcalo, a viteška / oklopja su cvit ki nosi. (I. GUNDULIĆ, 1964, 137)

${ }_{95}$ Na zamjernu na jedinu / njih bjeloću svijetlu izbranu / bistri jezer ončas sinu, / živim ognjem voda planu; / ozelenje kraj u travi, / trava u cvitju osta okoli, / bližnje dubje po dubravi / grane $u$ vodu skloni doli. (I. GUNDULIĆ, 1964, 121)

Nu kći kralja od Mogora / ljepša i svjetlja svih se ukaza: / njoj iz bijelijeh prsi zora, / sunce istječe iz obraza. (I. GUNDULIĆ, 1964, 121)

96 Gdi si, o sunce mojijeh dana, / vjereniče gdi si mili? / o mâ željo uzdisana, / u životu, jaoh, jesi li! / O životu moj jedini, / ja bez tebe nijesam živa, / ako u mrkloj s tobom tmini / srce $i$ duša ma pribiva." (I. GUNDULIĆ, 1964:69)

"Tvoj vjerenik sužan osta / i uza mu se na vrat stavi, 7 a ti cviliš jak priprosta 7 pastirica $u$ dubravi? / Na ku išteš bolju zgodu 7 da tvoj život igda odrediš, 7 ako sad ga za slobodu / vjerenika tvoga štediš? / Probudi se tim, probudi! (I. GUNDULIĆ, 1964, 73)

97 O bojnice svijetla imena, / u kom mjestu, u koj strani / nije tva slava razglašena? / Tve je ime proletjelo / i gdje svijetlo sunce gleda, / tve viteško svako djelo / za čudo se svud spovijeda. (I. GUNDULIĆ, 1964, 67) 
govore stihovi u kojima, saznavši da Korevski ima ljubavnicu, ona predstavlja idealnu ženu koja, unatoč njegovoj nevjeri, želi njemu ostati vjerna. Pa tako ga tražeći, da sazna očitu istinu o prevari, upada u neprijateljski tabor, gdje je zajedno s njim i pogubljena. ${ }^{98}$

Treći važan ženski lik ovog djela je lik Sunčanice koju otima Kazlar-aga. Uz njezin lik veže se motiv robinje, motiv o zarobljenoj djevojci koja vezana tuguje. Dakle, Sunčanica je još jedna od hrvatskih robinja. ${ }^{99}$ Kako je car tražio ženu, morala je biti visokog roda, a glas o Sunčaničinoj ljepoti bila je na širokom glasu. ${ }^{100}$ Imala je slijepog oca Ljubmira, kojemu je bila najveći oslonac i sve blago svijeta. Sunčanica je, osim što je služila ocu, služila i Bogu. Obvezala se na čistoću pa se samim time javlja suosjećanje s njezinim likom i preziranje Turaka koji su je oteli. Nakon što je oteta, Ljubmir jadikuje za svojom miljenicom, a Sunčanica kao tipičan lik robinje jadikuje nad svojom sudbinom. Njezina ljepota opisana je nadnaravno, kao tipični ženski petrarkistički lik. Ona je uspoređivana s rajem i suncem, koja uz čistoću izaziva kod čitatelja simpatije prema nesretnoj djevojci. U trenutku kada je oteta, ona je prikazana kao blijeda, nijema, bez uzdaha, zapanjena, više mrtva nego živa, brine za čistoću svoga tijela, čime se opet aludira na njezinu religioznost. Ona je prikazana kao tipična petrarkistička idealna žena, koja na kraju biva spašena ${ }^{101}$. Zadnja žena u Osmanu, okarakterizirana je kao potpuna suprotnost od prethodna tri lika. Mustafina mati okarakterizirana je kao ohola žena, koja baca kletve i čini, demonska žena. U jednom dijelu, ona je okarakterizirana kao vještica, a demonizacija je bila uvjetovana vjerovanjem o ženskoj podložnosti zlu. Predaje o vješticama ${ }^{102}$ duboko su ukorporirane u narodnu tradiciju dubrovačkog kraja, a pripisivala im se pojava bolesti i smrti, propale ljubavi, otkrivanje krova kuće i ostalo ${ }^{103}$. U potpunoj kontradiktornosti

98 Ti nevjeran meni budi, / ja ću tebi biti vjerna! (I. GUNDULIĆ, 1964, 182)

99 M. KOMBOL - S. PROSPEROV NOVAK, 1996.

100 Ali ovako Kazlaraga / jezdeć začu glas pun slave / od uresa lijepa i draga / Sunčanice prigizdave; / i kako se biješe ova / djevojčica svijetla i mila / sred bijeloga Smederova / plemenito porodila. (I. GUNDULIĆ, 1964, 90)

101 Paće bijelijem danom svanu / Crnom agi noćno lice / Na ljepotu rajsku izabranu / Od sunčane Sunčanice. // Zapažene odsvud vidi / U nju jednu svačije oči / I cvijet sunce gdi ju slidi / Pored suncem od istoči." (I. GUNDULIĆ, 1964, 101)

102 S. STOJAN, 2003.

103 Ona sama usred tmina, / u najgluše doba od noći, / kad zasjede ke zapina / zovuć pakô k svôj pomocii, / s lijevom nogom stane izutom / raspasanoj u haljini, / prospe kose, crnijem prutom / oko sebe krug učini. (I. GUNDULIĆ, 1964, 20); Noći leti vragoduha, / na kom jaše sved bez straha / k planinskomu vilozmaju, / gdi vještice podno oraha / na gozbe se strašne staju." (I. GUNDULIĆ, 1964, 21) 
s ostalim ženskim likovima, Mustafina majka ima nadnaravne moći, sposobna je činiti strašna djela, okrvaviti mjesec, zacrniti nebo, tresti zemlju, mutiti more. Također je sposobna preobraziti se u ptice, zvijeri, stijene pa su tako u njezin lik utkane moći koje se nalaze i u bajkama i predajama. ${ }^{104}$ Ona nije lijepa žena, zla je i ohola, jedini cilj joj je smaknuti Osmana i osloboditi Mustafu iz zatvora da vladaju carstvom. Zaslijepljena je moći, vladavinom i raskošem.

\subsection{Mandalijena pokornica}

Ivan Bunić Vučić jedan je od najznačajnijih i najboljih liričara čitave starije hrvatske književnosti. Od duhovne poezije napisao je Mandalijenu pokornicu zbog koje su ga suvremenici slavili. U Mandalijeni ljubavne su konvencije mogle doći do izražaja zbog faze sagrješenja. Ljubavna topika gotovo je ista kao u njegovoj lirici, samo je okrenuta nebeskom ljubovniku. Na nekim mjestima se događa da je Mandalijena još ljepša u raskajanosti. ${ }^{105}$

Mandalijena pokornica religiozna je poema napisana u tri cviljenja, a govori o grijehu i pokajanju Marije Magdalene te o njezinoj ljubavi prema Kristu i obrnuto. Mandalijena je opisana kao javna grešnica koja, shvaćajući svoj grijeh, prezire sve ovozemaljske užitke pa želi postati ružna svijetu kako bi postala vjerna Bogu. Zbog toga se počinje stidjeti svoga tijela i haljina te općenito svoga izgleda koji je mnoge muškarce odveo u propast. ${ }^{106}$ Opisana je kao petrarkistička ljepotica, što uključuje opise njezine kose, odjeće i nakita ${ }^{107}$ te kao bludna, varljiva i nečasna žena. Mandalijena zaluđuje muškarce navodeći ih da se klanjaju njezinoj ljepoti te biva u središtu pozornosti, a svojim peharom smatra osvojenje što većeg broja muškaraca. Smatrala je da njezina vrijednost raste sa što većim brojem ljubavnika te je svu pozornost zbog toga usmjeravala na svoj tjelesni izgled. Opisana je i kao žena koja je mladićima pružala osmijeh, razbuktavajući njihovu strast. ${ }^{108} \mathrm{U}$ trenutku kada Isusov pogled postaje ključni

104 D. FALIŠEVAC, 2007.

105 M. FRANIČEVIĆ et al., 1974.

106 Naprave je sve razvrgnula / pokajana pokornica / s grla obli biser vrgla, / digla s glave sva cvjetica. // S uha smače ušerezi, / a verigu zlatnu s vrata, / i drag kami kijem se uresi, / ki je bisera draži i zlata. (I. BUNIĆ VUČIĆ, 1975, 175)

107 Sviona odjeća, ku naveze / zlato, biser i drag kami, / njoj mlađahnoj donese se / s mnozijem druzijem napravami. // Bijeli velak $i$ koprena / nje snježane prsi odiva, / tako 'e hitro istrižena / da ih kaže, a ne skriva. // Jedan dio zlatnijeh kosi / sveza, srudi i zaplete, / drugi pusti da ih nosi / vjetric i da same lete. (I. BUNIĆ VUČIĆ, 1975, 171)

108 Nijekom posmijeh svoj otvora / kijem mu misli razveseli, / njekom jasnos od pozora / kijem mu odkriva dan pribijeli. // Nijekom riječcu razbluđenu / šapće tiho u prohodu, / nu ne dobro 
u njezinom preobraćenju, nastaje ljubav koja je okarakterizirana kao ljubav na prvi pogled. Ta njezina ljubav opisana je petrarkistički, ali ovoga puta kao ljubav prema nadnaravnom od strane žene pa tako Mandalijena vene, blidi, gasne, gine, plače, cvili, čezne i izdiše. Ona potom suzama oplakuje svoje grijehe, a te suze zatim postaju simbol jedinstva duše i tijela, zemaljskog i nebeskog, sjedinjenja duše s božanskim. Iako su suze izvanjski znak kajanja, one nisu bile dovoljne za potpuno iskupljenje grijeha. ${ }^{109}$ Njezino bludničenje, kićenje i uređivanje nije moglo biti iskupljeno suzama, stoga se ona istinski kaje te govori o svom odlasku u pustinju koja je mjesto samoće i u kojoj nema kušnji. ${ }^{110}$ Tako je Mandalijena u špilji prestrašena, blijeda i zapanjena, u suzama i krvi, više mrtva nego živa u borbi s prijašnjim životom. Srami se svojih grijeha i promatra svoje propuste. Vraća se kao pokajana razbludnica, svjesna tjelesne prolaznosti te nevažnosti ispraznih zabava u čijem je središtu pusta raskoš.

Ona je primjer žene kojoj je Bog oprostio grijehe zbog njezinog iskrenog kajanja. Samo odlazeći daleko od ljudi, bez uživanja ikakvih dobara, mogla je istinski spoznati sebe i svoje grijehe. ${ }^{111}$

\subsection{Uzdasi Mandalijene pokornice}

Ignjat Đurđević svoje je mjesto u našoj književnosti stekao religioznom poemom Uzdasi Mandalijene pokornice ${ }^{112}$. Baš kao i kod Bunićeve, i u Đurđevićevoj Mandalijeni ključnu ulogu ima Marija Magdalena kod koje su također prisutne razne tradicije.

Međutim, u Đurđevićevoj Mandalijeni prepoznaje se i utjecaj legende o Mariji Egipćanki, pokajanoj bludnici. Baš kao kod Bunića i kod Đurđevića se također pronalaze elementi pustinjaštva i odricanja od zemaljskih dobara. Mandalijena se u špilji posvećuje postu i molitvi. Kao i Marija Egipćanka i Mandalijena je kažnjavala svoje tijelo bičem, jela gorko zelje i trpjela zimu i glad. ${ }^{113}$ Bičevanjem je dokazivala svoju spremnost na pokoru, pokušavajući

razumijenu / da ga drži u zahodu. // Sva je u varki i hitrini, / sve svo'e želje taji i krije, / sva je izdajstvo, u svem hini, / u nevjeri vjere nije. (I. BUNIĆ VUČIĆ, 1975, 172)

109 M. TATARIN, 2010, 223-255.

110 Dvor s pustinjom promijeniću, / jestojska mi biće trava, 7 odar zemlju učiniću / ševar mi će biti naprava. // Bih gospođa, biću sužna, / pritvoriću bitje i sliku, / lele, lele veomi tužna / da ne osušim lica viku. (I. BUNIĆ VUČIĆ, 1975, 178)

111 Detaljno o baroknom stilu pisanja Ivana Bunića Vučića pogledati D. FALIŠEVAC, 1998, 107-115.

112 M. FRANIČEVIĆ et al., 1974.

113 M. TATARIN, 2010, 223-255. 
pobijediti napast i bludne misli. ${ }^{114}$ Pusto ozračje uz špilju odraz je njezinog duhovnog stanja pa tako špilja postaje metafora njezine duše. ${ }^{115}$ Budući da je ostala na osami, Mandalijena se prisjeća vremena kada je bila izrazite ljepote, okružena mladićima i djevojkama. Sjeća se svog nekadašnjeg života, dvora i zlata. Tek u špilji ona postaje svjesna svojih grijeha koji joj izazivaju nemir te pokušavajući pobjeći od njih, između plača i uzdaha, kaje se govoreći bez srama o svojim grijesima želeći da je svijet vidi ružnu. Kao Bunićeva Mandalijena, i Đurđevićeva je opisana petrarkistički. ${ }^{116}$ Pronalazak prave ljubavi dogodio se u trenutku kada je ugledala Isusa. Pred njegovim licem, ona ustaje iz pepela pokretom feniksa i tako postaje simbolom obnove. Ona ostavlja svoj prijašnji život i promatra ljubav drugačije. Petrarkistički stihovi očituju se Mandalijeninim govorom. Ona idealizira Isusa, doživljava gorku ljubav i patnju. Kako su petrarkistički pjesnici patili za svojom gospojom, tako je i Mandalijena patila za svojim zaručnikom. Ona se od ljubavi želi pretvoriti u vatru i izgorjeti. Međutim, Božja milost vodi nadzemaljskom vjenčanju, a kako se kaje Mandalijena je proglašena sveticom.

\subsection{Pavlimir}

Junije Palmotić označio je prekretnicu posežući za građom u eposima rimskih i talijanskih pjesnika te dijelom u domaćim kronikama na način koji je značio bijeg od suvremenih problema. I prije su se iskorištavali motivi iz antičke književnosti i mitologije, ali nisu bili u toj mjeri dominantni. Pavlimir je jedina njegova drama utemeljena na domaćim izvorima, odnosno na jednom poglavlju iz Ljetopisa popa Dukljanina koji označava povratak Pavlimira, unuka prognanog kralja Radoslava, iz Rima na djedovsko prijestolje. ${ }^{117}$

U Palmotićevim dramama jak je čudesni element pa se tako u njegove drame upleću čarobnice, vile, patuljci i slične pojave. U Pavlimiru zli duhovi Tmor i Sniježnica dižu oluju na moru, bune protiv Pavlimira stanovnike

114 Vidje vihre bit planinu, / - udri bičim nago tijelo; / izgleda se blijedu u tminu / i bljedilom prikri čelo; / plahe zvijeri vidje u gori, / i za boga zvijer se stvori. //Zlato, kijem se pram dičio, / na svenuto priđe lice; / od usta je trator mio / uzeo sliku od ljubice, / a svakdanji biči ljuti / poraziše lijere od puti. (I. ĐURĐEVIĆ, 1971, 267)

115 Gluha zabit, mrak od spile, / strah i golet, glad i zima / biše srcu nje primile, / er nemile bjehu očima, / čijem plam ište nje požude / veće u trudijeh istijeh truhe.(I. ĐURĐEVIĆ, 1971, 293)

${ }_{116}$ Pak na prame ruku uzdižem / $i$ njih mučé sebe trudim; / pravim, dijelim, skubem, strižem, / spuštam, pletem, vežem, rudim, / dokle učine u dva dijela / zlatnu dugu suncu od čela. (I. ĐURĐEVIĆ, 1971, 299)

117 M. FRANIČEVIĆ et al., 1974. 
okolnih krajeva, dok Srđ pomaže Pavlimiru i pobjeđuje zle sile. ${ }^{118}$ Drama Pavlimir zastupa tri tematska svijeta: kršćansko-pastoralni u kojemu su Margarita, Srđ, Dubravko, Dubravka, Vilen i pastir; zatim viteško-povijesni u kojemu se nalaze Pavlimir, savjetnik, Pavlimirova družina, Krstimir i družina te glasnik; i zadnji tematski svijet je mitološko-fantastični čiji su predstavnici Tmor, Sniježnica, Strmogor, vilenici i nakazi pakljene. ${ }^{119}$ Sniježnica je okarakterizirana kao zla nemilosna vilenica čiji je cilj onemogućiti Pavlimiru osnivanje grada Dubrovnika. Zajedno sa svojom družinom šalje vojsku od vjetra da potopi neprijateljske brodove, odnosno Pavlimirove brodove. Međutim, vojska od vjetra nije jedna stvar koju Sniježnica radi protiv Pavlimira. Ona, zajedno s Tmorom ima plan da sve Pavlimirove sugrađane okrene protiv njega. Ustrajna je u svojoj nakani da ubije Pavlimira. Međutim, kada dođe do tog trenutka, Sniježnica se preobrati, zaljubi se u Pavlimira i u sve ono što je nekada kod njega mrzila. ${ }^{120}$ Od svoje silne ljubavi i zaluđenosti Pavlimirom, Sniježnica se htjela pretvoriti u Margaritu ne bi li tako zadobila njegovu ljubav. Zbog ljubavi, ona se ostavila svog pakosnog života, ali vile su otkrile njezin plan pa je morala pobjeći. Ona se na kraju kaje zbog svega, uviđajući kako joj pakost i varanje ništa dobroga nisu donijeli u životu. ${ }^{121}$ Kao njezin kontrast javlja se Margarita, lijepa i dobra vila. Njezin lik se prikazuje kao idealan ženski barokni lik, vjeran Bogu, iskren i nevin. Ona nije imala nikakvog doticaja s muškarcima što joj daje posebnu čar. Ona sve stavlja u Božje ruke i smatra kako je njezina sudbina već određena pa tako samo stoji i čeka svoju budućnost. ${ }^{122}$ Ona je osvojila Pavlimirovo srce svojom ljepotom i dobrotom pa je on stavlja na prvo mjesto u svom životu, čak ispred domovine. Baš kao što Pavlimir voli nju, tako je i ona njemu dala svoje srce. Margaritina ljubav je velika i iskrena, a u trenutku kada misli da ju je Pavlimir napustio, uočava se njezina skromnost. Ona moli Pavlimira da je uzme za svoga slugu što ukazuje na količinu njezine ljubavi i njegovog značaja u njezinu životu.

118 M. KOMBOL - S. PROSPEROV NOVAK, 1996.

119 M. KOMBOL - S. PROSPEROV NOVAK, 1996.

120 Ja se spravljah da pogubim / kralja, moga protivnika; / mješte omraze sad ga ljubim, / $i$ za njime mrem bez lika. // U srce mu još krvavi / hotijah zabit handžar ovi; / ali on srce moje ulovi / jakom strijelom od ljubavi.(J. PALMOTIĆ, 1965, 325)

${ }_{121}$ Da li tuđu noseć sliku / ja ovako ostah ružna; / lele, lele veomi tužna / da ne osušim lica viku! / Proklet budi ko najprije / naučio je varat mene, / od nauke kad himbene / pomoći mi nijedne nije. (J. PALMOTIĆ, 1965, 349)

122 Bogu davam ja se u ruke / $i$ sniženo njega molju / da on ispuni mu odluke, / da on vlada moju volju. (J. PALMOTIĆ, 1965, 295) 
Iako iskreno voli, ona se opravdava Bogu da, ukoliko se radi o nečistoj ljubavi, neće učiniti ništa što je protiv Njegove volje. ${ }^{123}$

\subsection{Armida}

U melodrami Junija Palmotića Armida dominira istoimeni glavni ženski lik i tri ženska zbora koje čine vile, sirene i nakazi pakljene. Ova melodrama tematizira boravak viteza Rinalda na fantastičnom otoku gdje su ga privukli glasovi o prekrasnoj čarobnici Armidi, u čijem će zagrljaju i razbludnoj dokolici uživati sve dok po njega ne dođu njegovi suborci. ${ }^{124} \mathrm{O}$ Armidinom podrijetlu doznaje se već iz Prologa. ${ }^{125}$ Također se doznaje da je nakon očeve smrti dobila zadatak da vjernu vojsku od krstjana rani, ustrijeli $i$ zanese. Međutim, kada je vidjela Rinalda kojega je trebala ubiti Armida se, kao Snježnica, zaljubi u svog neprijatelja. Iz Karlovog i Rinaldovog razgovora doznaje se da je Armida bludnica, ${ }^{126}$ opisana kao petrarkistička ljepotica, koja je očarala Rinalda koji s njom uživa na otoku Sreće gdje ga je ona odvela da zauvijek budu zajedno. Armida je zla vila koja sebično upravlja magijom ljubavi, razmišljajući samo o svojoj sreći. Rinaldo, zanesen ljepotom, odnosno Armidinom magijom, ne razlikuje stvarnost od fikcije. ${ }^{127}$ Međutim, Karlo i Ubaldo spašavaju Rinalda, zbog čega Armida postaje nesretna, tuguje za Rinaldom, njegovom ljubavi, pitajući se kako ju je mogao ostaviti samu i zaziva paklene sile. Armida je prikaz demonske žene i žene bludnice koja živi u nadnaravnom okruženju sa svojim nadnaravnim moćima. Baš kao i Snježnica, zaljubljuje se u muškarca čijem svijetu ne pripada. Zbog njega pati, rabi moći, čini sve da je zavoli, ali uzalud.

${ }^{123}$ Moja mlados ne dostoji / kraljica se tvoja zvati, / ti mê srce, kralju osvoji, / i ti ćeš mu kraljevati. / Svud sam doći s tobom spravna, / moj životu dragi i mili, / tva dobrota vrijedna i znana / moje želje slatko sili. (J. PALMOTIĆ, 1965, 262)

124 N. BATUŠIĆ, 2008.

125 Lijepa Armida, ke na sviti / čudna je lijepos i hitrina, / nu nje porod glasoviti / sva nadhodi čuda ina. / Plemenita nju Sirena / kon Eufrate rijeke rodi, / koja od kralja bi ljubjena, / ki Damaškom jur gospodi. / Sirena ova rajskom dikom / svoga glasa i ljepote / srca mnozijem ljubovnikom / zanosaše i živote. (J. PALMOTIĆ, 1883, 414)

126 Na višemu lijepa vila / sjedi, a vitez u pokoju / sred mekahma njeje krila / naslonio glavu svoju. // Nu ti prama rudijeh kosi, / ke ona plete svjetlje od zlata, / snježanoga oko vrata / bludni vjetrić njoj raznosi. // Zrcalo joj vitez drži, / gdi ona ogleda svoje lice; / ah, himbene vilenice, / ko ga travi, ko ga prži. (J. PALMOTIĆ, 1883, 426)

127 O Armida, ma gospoje, / o razbludo moja mila, / ka si ognjene želje moje / zlatnijem pramom zatravila, / zrak sunčanijeh vedrijeh oči / svrni na me, er je meni / draži od sunca od istoči / tvoj drag pogled i ljubjeni. / Od nebeskijeh tvojijeh dika, / kojijem srce me zamami, / ako ne znaš, prava slika / ljuveni su moji plami. (J. PALMOTIĆ, 1883, 427) 
One su vile koje uzrokuju pakosti, hirovite su i osvetoljubive. Žene su zbog svog prevrtljivog i krhkog karaktera bile često povezivane s vještičarenjem. ${ }^{128}$

\section{Od gospoja do čarobnica}

Još u starokršćanskoj književnosti žena je bila razapeta između dviju krajnosti izraženih u likovima dviju žena: Eve i Marije. Dok Eva predstavlja ženu u njezinoj egzistencijalnoj slabosti i krivnji, Marija predstavlja cilj i ideal $\mathrm{s}$ kojim se svaka žena treba poistovjetiti. Evi je pripisana odgovornost za prvi grijeh, stoga je povezanost svih žena s istočnim grijehom postao izvor njezina podcjenjivanja. ${ }^{129}$ Zbog čežnje i potrebe da se žena očisti od grijeha i nađe svoj put od Eve do Marije, u književnosti se nailazi na različite tipove žena. U hrvatskoj književnosti renesanse i baroka mogu se uočiti različiti profili žena: od žena junakinja, ratnica, dobrih žena, petrarkističkih gospoja, žena bludnica pa sve do žena čarobnica i vještica.

Hrvatski su petrarkisti slaveći zamišljeno ili stvarno žensko biće i posvećujući svoje stihove idealnoj gospoji razvili bogat pjesnički jezik i specifičnu metaforiku poštujući normu ljubavnog kanconijera. Džore Držić i Šiško Menčetić u svojim su pjesmama strogo poštivali norme ljubavne užganosti, zadivljenosti gospojom od prvog pogleda i blagoslivljanja trena kada je pjesnik ugledao gospoju pa sve do ljubavnih muka. ${ }^{130}$ Radi se o idealnoj ženi i gospoji koja svojom ljepotom uspijeva očarati naše pjesnike, iako se petrarkistički opisi nalaze i u opisima žena koje su bludnice, ratnice ili čarobnice. Kao žene ratnice koje su petrarkistički opisane može se spomenuti Judita, Krunoslava i Sokolica, ${ }^{131}$ žene koje su lijepe i iznutra i izvana i čija ljepota iz unutrašnjosti prelazi na vanjski izgled. U kontrastu sa ženama ratnicama nalaze se neutralne dobre žene koje nemaju nikakvog utjecaja na svoj život, ali čija je ljepota pokretač radnje. Primjeri takvih žena su Dubravka, Robinja, Suzana, Sunčanica i Magdalena. One su žene prepuštene božjoj volji ili volji nekih viših sila, same ne utječu na svoju sudbinu i sudbinu ostalih likova. U čistoj suprotnosti s idealnom ženom koja je slavljena zbog svoje čestitosti i ljubavi, stoji Držićeva Laura koja je žena bludnica, baš kao i žena iz Gundulićevih Suza te Bunićeva i Đurđevićeva Mandalijena. One su sve bludne žene koje su muškarce zavele svojom ljepotom, koji su potom

128 S. STOJAN, 2003.

129 A. MIŠIĆ, 1990, 495-510.

130 B. PETRAČ $1991,348-354$.

131 O stilu u hrvatskoj renesansnoj i baroknoj epici i o načinima prikazivanja svih spomenutih likova pogledati D. FALIŠEVAC, 1994, 39-49. 
gubili bogatstva i sramili se svojih postupaka. Možda se najneobičniji primjer petrarkističke ljepotice nalazi u Armidi, bludnici i čarobnici o čijoj se ljepoti pričalo i koja je svojom ljepotom začarala muškarca kojeg je trebala ubiti. Sve spomenute žene prikazane su kao petrarkističke ljepotice, međutim, nisu sve samo ljepotice, nego su mnoge od njih i žene ratnice.

Tip žene ratnice karakterističan je za cjelokupnu stariju hrvatsku književnost, žanrovski dominantan u epskom pjesništvu. To je tip jake i uzorne ženske figure koja se žrtvuje za opće dobro, za zajedničku, nacionalnu stvar. ${ }^{132}$ Takav tip žene u hrvatskoj književnosti razvija Marko Marulić tražeći motiv u biblijskoj junakinji Juditi. Premda je njegova Judita bila žena ratnica, potrebno je istaknuti da je i ona također prikazana kao petrarkistička ljepotica koja je svojim izgledom spasila cijeli svoj narod. Iz opisa njezine ljepote možda bi se moglo reći da je ona bludnica zbog načina na koji ukrašava svoje tijelo, ali Juditu je potrebno proučavati u cjelini pa se upravo zbog toga može zaključiti kako se ona ukrašavala kao i ostale žene bludnice da bi zavela svog neprijatelja kojeg je naposljetku i ubila. Dakle, njezin cilj i jest bio zavođenje, ali ipak glavni cilj bio je ubojstvo neprijatelja i spašavanje naroda. Zbog njezinih namjera ona se može svrstati u grupu žena ratnica. Osim toga, Judita je postala simbol za hrabrost i važnost svakog pojedinca, a osobito važnost žena. Žene, koje su dotad bile samo simbol ljepote, iskušavaju se i u velikim podvizima, hrabrim djelima, ulaze u rat, spašavaju cijelu naciju. Uz Juditu, kao primjeri žena ratnica ističu se i Gundulićeve Sokolica i Krunoslava. One su hrabre žene koje, svaka na svojoj strani, brane svoju vojsku i svoje muškarce. Dok se Krunoslava obvezala na ljubav te zbog te iste ljubavi i kreće u rat tražeći svoga zaručnika, Sokolica bježi od Osmana jer joj je draža sloboda od ljubavi. Iako su prikazane kao snažne žene, žene ratnice, iz djela se može iščitati i njihova osjetljivost, osjećajnost i ljubav. Njihova muškost ipak nije uspjela nadjačati ženstvenost koju imaju u sebi pa je tako Sokolica zbog svoje ljepote i ženstvenosti izbjegla smrt. I Krunoslava i Sokolica su opisane kao iznimne ljepotice, svaka sa svojim vrlinama. Krunoslavu krasi zlatno oružje kojim se odlično služi, visoka je kao jela, a Sokolica brza i ponosna poput sokola. Sve tri navedene žene ratnice imaju jednu zajedničku osobinu, a to je hrabrost. One su iskušale u nečemu u čemu se ni neki muškarci ne bi usudili, borile su se za ljubav i za svoj narod, za svoje osobne ciljeve i ciljeve svojih sugrađana, ne razmišljajući o mogućim posljedicama hrabro su koračale naprijed ne posustajući pred preprekama. Razlika između Judite i Gundulićevih ratnica je ta što je Judita utjecala na sve likove, ona je pokretač i

132 B. PETRAČ, 1991, 348-354. 
prekretač radnje, dok Osmanove junakinje imaju utjecaj jedino na svoju sudbinu, ali ne i na događaje i ostale likove. U suprotnosti sa ženama ratnicama nalaze se neutralne žene, dobre žene koje nemaju nikakvog utjecaja na svoju sudbinu i sudbinu ostalih likova.

Dobre žene su također i žene ratnice, međutim pod sintagmom dobre žene podrazumijevaju se žene čija je jedina uloga u djelima dobrota, a ne njihovo sudjelovanje u djelu. One su pasivne, nisu aktivne sudionice djela pa jednostavno čekaju svoju sudbinu da se dogodi. Prepuštene su svima osim sebi, često i oplakuju svoju sudbinu koja ih je snašla, a ne poduzimaju ništa po pitanju promjene svoga života. One su u potpunosti neutralne, ne utječu na tijek djela, ne sudjeluju u radnji, one samo postoje. Prvi primjer dobre žene je Gundulićeva Dubravka okarakterizirana kao najljepša pastirica, petrarkističkim slikama slavi se njezina ljepota i dobrota, ali drugu ulogu u djelu nema. Ona je prepustila svoj život na milost i nemilost višim silama, oplakuje svoju sudbinu u nadi da će se nešto okrenuti u njezinu korist što se na kraju i dogodilo zbog njezine dobrote. Uz Dubravku, kao primjer dobre i čestite žene može se navesti i Marulićeva i Vetranovićeva Suzana koja je zbog svoje dobrote, ljepote i čestitosti skoro osuđena. Suzana, kao i Dubravka, ništa ne poduzima po pitanju obrane svoje časti, ona prepušta sve Bogu od kojeg moli da je spasi. Ona biva spašena, baš poput Dubravke, kada istina izlazi na vidjelo, a one zbog svoje dobrote pronalaze izlaz. I Lucićeva Robinja sklona je oplakivanju svoje sudbine, a kao i prethodne dobre žene opisana je petrarkističkim slikama. Međutim, njezina mana je oholost zbog koje ipak ne može biti izbačena iz kategorije dobrih žena jer je ta oholost opravdana prijašnjim načinom života zbog kojeg nije smjela pokazati svoju ljubav mladiću kojeg je voljela. Žene iz Pelegrinovićeve Jeđupke također su sve redom dobre žene, svaka sa svojim ljubavnim i životnim problemima. Njih se svrstava u dobre žene zato što pomoć traže od Ciganke, nadajući se da će rješenje doći samo od sebe, tražeći izlaz u čarobnim travama, pasivno promatrajući kako se njihov život odvija pokraj njih. Gundulićeva Sunčanica i Palmotićeva Magdalena najbolji su primjeri pokornih i čestitih, dobrih žena koje su svoj život prepustile Božjoj volji. Sunčanica je žena koja u svoj svojoj nevolji vidi samo Boga, traži njegovu pomoć i spas, moli Ga da joj sačuva djevičanstvo i čestitost. Dok ona traži Božju pomoć u nevolji, Magdalena od Boga traži da je sačuva od pogrešnog izbora. Prepušta Bogu na volju svoj život i svoju ljubav, pasivno čeka svoju sudbinu.

Žene bludnice na određen su način povezane s petrarkističkim gospojama, a ipak one su njihov antipod. Njihova ljepota je njihov najveći adut, one muškarce odvode na krivi put i zbog njih su bludni. Držićeva kurtizana 
Laura pravi je primjer žene bludnice. Ona je ljepotica za čiju se ljubav i milost bore mnogi muškarci. Za razliku od Petrarkine Laure s kojom dijeli ime, ona nije čestita žena, ne teži idealu i ljubavi. Njezine težnje usmjerene su prema dukatima prema kojima bira muškarce. Dok je Laura u cijelom djelu prikazana kao iznimna ljepotica, žena iz Gundulićevih Suza prikazana je kao prividna ljepotica. Ta ljepotica se u jednom trenu pretvara u rugobu koja je odgovorna za propast muškarca i njegova života. Opis njezine ljepote kasnije postaje pričina, odnosno petrarkistička koncepcija ženske ljepote pretvara se u ideološku koncepciju demonskoga lika. ${ }^{133}$ Žena iz Suza i Mandalijena opisane su kao bludnice koje kao lavovi traže svoj plijen i kite se nakitom kako bi privukle pozornost. Izvor grijeha bilo je žensko tijelo samo po sebi, a uz pomoć različitih naprava, ukrasa i parfema muškarac je postajao žrtva ženskih lukavstava. ${ }^{134}$ Razlika u ženama bludnicama ipak postoji. Žena iz Suza je grešna bludnica koja nije svjesna svojih postupaka, odnosno ne pokazuje kajanje zbog svoje bludnosti. Mandalijena je ipak tip bludnice pokajnice koja se nastoji pokajati za svoj grijeh kako bi ponovno zadobila Božju milost. Ona je žena koja je prošla od svjetovnog ideala ljepote i nedostižnosti, tj. gospoje, do simbola svjetovnog zla, odnosno grešnice, da bi se na kraju preobrazila u biće koje se svojim kajanjem uzdiže i posvećuje. ${ }^{135}$

U žene čarobnice mogu se svrstati vještice i vilenice. Vještice su negativne ženske osobe koje žive u lokalnoj zajednici. ${ }^{136}$ Prema tome, Mustafina mati primjer je vještice koja živi sa svojim sugrađanima, djeluje na istim područjima kao i oni, ima jednaka prava, ali posjeduje nadnaravne moći, sposobna je preobraziti se u neku životinju, upravlja morem i nebom te ljudskim životima. Za razliku od vila, ona je ružna žena koja se sastaje pod orahom čija je mistična moć neobjašnjena i nosi obilježje mjesta na kojemu se sastaju vještice. ${ }^{137}$ Zajednička osobina žena čarobnica, u koje uz Mustafinu mati spadaju i vilenice Sniježnica i Armida, je ta da se sve tri bore protiv kršćanskoga naroda. Međutim vilenice Sniježnica i Armida odustaju od tog poteza zbog ljubavi, što nije slučaj s Mustafinom majkom. Vilenice su najčešće žene, uglavnom mlade djevojke, privlačnog izgleda, svijetle puti, plave kose, plavih ili zelenih očiju, vitka izgleda. ${ }^{138}$ One se ne kreću kao ljudi, već lete

\footnotetext{
133 B. PETRAČ, 1991, 348-354.

134 M. TATARIN, 2010, 223-255.

135 B. PETRAČ, 1991, 348-354.

136 A. JURETA, 2017, 43-57.

137 A. JURETA, 2017, 43-57.

138 A. JURETA, 2017, 43-57.
} 
po zraku, a njihovo djelovanje je ambivalentno. Ono najviše ovisi o čovjeku i njegovom ponašanju. Armida je vilenica ali i žena bludnica koja je svojom ljepotom začarala Rinalda te ga odvela na otok da uživaju sami u svojoj ljubavi. Ona i Sniježnica su se zaljubile u svoje neprijatelje u istom trenutku kada su ih ugledale. Za razliku od nje, Sniježnica nije imala tu sreću uživati u ljubavi svog neprijatelja. Ona je zla vilenica koja se na kraju ipak kaje zbog svojih djela pa se u tom pogledu može čak usporediti i s Mandalijenom. Baš kao i Mandalijena i Sniježnica je za svoju kaznu odabrala progonstvo kako bi se iskreno pokajala zbog svih svojih grijeha.

\section{Zaključak}

Provedeno istraživanje ženskih likova iz razdoblja renesanse i baroka dovodi do spoznaje o širokom rasponu ženskih likova te o različitim odnosima muškaraca, ali i okoline, prema njima.

Od samog postanka svijeta žena je nosila teret grijeha. Eva je počinila zlo kojim je osudila sve žene da svjesno ili nesvjesno ispravljaju njezin grijeh. No, osim što je ženama dala vječni teret, ona je od njih napravila zla bića samim time što je muškarca nagnala na grijeh. Iz tog grijeha proizlazi muškarčev strah od žena kao zlih i bludnih bića koje muškarce mogu odvesti jedino u propast. Tako je već u srednjem vijeku žena bila u nezavidnom položaju u kojemu nije imala pravo sudjelovanja u javnom životu, izlaska na ulicu te općenito samostalnog pojavljivanja izvan svoga doma. Osim što je imala apsolutnu zabranu nad svim osnovnim ljudskim pravima, također je imala i zabranu primanja znanja jer je smatrana labilnim bićem. Iznimku su u nekoj mjeri činile žene iz vladarskih i aristokratskih krugova, koje su u trubadurskoj poeziji bile svojevrsne preteče petrarkističkih obožavanih dama.

Dolaskom renesanse položaj žena se promijenio. Muškarci su se poklanjali njihovoj ljepoti, žudjeli za njihovom ljubavi, pjevali svojim gospojama, uspoređivali njezinu ljepotu i dobrotu s uzvišenom Djevicom Marijom. Ženska je tjelesnost bila bazirana na djevičanstvu i neiskvarenosti. Ono se idealiziralo pa je ženska čistoća postala mjerilo za vrijednost žene. Mnoga renesansna djela nastala su na temelju biblijskih priča o hrabrim i čestitim ženama. One su petrarkističke ljepotice koje su iznad svoje ljepote snažne i odlučne žene koje čine sve za svoj narod. Renesansa nudi pregršt ženskih likova koji su više ili manje objekt muških požuda, njihovih želja i maštanja. S jedne strane stoji udovica koja ljepotom oslobađa svoj narod od neprijatelja, a s druge strane kurtizana koja prodaje svoje tijelo za novac. Žene renesanse kreću se od pasivnih do aktivnih 
likova, od ratnica preko dobrih žena do žena bludnica. Njihovi karakteri uvelike se razlikuju u njihovim djelima i odnosu prema svome tijelu. Njihovi profili grade se ne samo na temelju njihovih postupaka, već i na temelju njihovog govora, pokreta i misli, odnosa s drugim likovima te njihovoj ulozi u djelu. Osim što se renesansna žena prikazuje kao uzvišena ljepotica, njoj se indirektno sugerira na jednakost s muškarcima. Tako Pelegrinović u Jeđupki jednoj od žena govori da uzvrati muškarcu istom mjerom, što se u ovom slučaju odnosilo na prevaru. Time se, doduše pod krinkom karnevala, postiže sasvim novi stupanj muško-ženskih odnosa, inovativno se nude rješenja koja nikada do tada nisu ženi ponuđena. Premda postoje ženski likovi koji aktivno sudjeluju u društvenom životu, svom osobnom životu ili utječu na sudbine drugih ljudi, većina renesansnih žena su ipak pasivne. One ne utječu na svoj život ni život drugih ljudi, oko njih se radnja odvija, one ne utječu na nju direktno, već uglavnom oplakuju svoj život i tešku sudbinu čekajući da se stvari same od sebe riješe.

U baroku se položaj žena iznova mijenja. Iako su petrarkistički opisi i dalje prisutni, barokne žene ipak više sudjeluju u izgradnji svoje sudbine. Kako u renesansi tako i u baroku postoje žene ratnice, međutim one više ne utječu na sudbinu cijelog naroda, čak ni svojih ljubavnika, već samo na svoju sudbinu. U baroku se sve više govori o ženama kao iskvarenim, nemoralnim i bludnim bićima. Njihova glavna uloga je zavođenje muškaraca, nagovaranje na blud i naposljetku odvođenje u propast. Javljaju se likovi pokajanih i nepokajanih bludnica. Nepokajane bludnice svjesne su svoje ljepote, moći zavođenja, uništavanja muškaraca, ali nisu svjesne svoga grijeha. Pokajane bludnice također su svjesne svoje ljepote, ali u trenutku susreta s Kristom postaju svjesne i svojega grijeha. One zatim odabiru svoj puta kajanja te kažnjavanja tijela kako bi se u potpunosti pokajale za svoje grijehe. U baroku se javlja novi tip žena - žene čarobnice, koje se prikazuju u liku vještica i vilenica. One su žene s nadnaravnim moćima. Žene vještice, za razliku od vilenica djeluju destruktivno za ostatak ljudi, dok vilenice djeluju destruktivno na kraju samo za sebe. Lik čarobnica duboko je ukorijenjen u književnosti, kao likovi koji lete na metlama, rabe nadnaravne moći ili se pretvaraju u neke životinje.

Lik žene u hrvatskim renesansnim i baroknim književnim djelima vrlo je raznoliko prikazan. Premda su u različitim književnim epohama, ti se ženski likovi ipak ne mogu razmatrati odvojeno. Oni se isprepliću u svojem izgledu, djelima i ponašanju. Ne samo da se ne mogu promatrati odvojeno od razdoblja, već se ne mogu svrstati u jednu skupinu na temelju ponašanja. Njihove karakteristike međusobno se isprepliću pa su tako žene ratnice ujedno i dobre žene i petrarkističke gospoje, jedna žena čarobnica je ujedno i pokajana, 
bludnica je petrarkistička ljepotica itd. O njima se govorilo i mislilo, imale su utjecaj na društvo i na svoj život i kao takve zavrijedile su analizu i iz perspektive današnjice.

\section{Izvori i literatura}

Nikola BATUŠIĆ, Armida, u: Dunja Detoni-Dujmić i sur. (ur.) Leksikon hrvatske književnosti: Djela, 21-22, Zagreb, 2008.

Tomislav BOGDAN, Lica ljubavi: status lirskog subjekta u kanconijeru Džore Držića, Zavod za znanost o književnosti Filozofskoga fakulteta Sveučilišta u Zagrebu, Zagreb, 2003.

Tomislav BOGDAN, Jeđupka, u: Dunja Detoni-Dujmić i sur. (ur.) Leksikon hrvatske književnosti: Djela, Zagreb, 2008, 292-293.

Rafo BOGIŠIĆ, Hrvatska i Europa: kultura, znanost i umjetnost: Srednji vijek $i$ Renesansa (13. - 16.st.), Zagreb, 2000.

Ivan BUNIĆ VUČIĆ, Mandalijena pokornica, u: Krsto Špoljar (ur.) Pet stoljeća hrvatske književnosti. Knjiga 14: Ivan Bunić Vučić, Zagreb, 1975, 169-205.

Adriana CAR-MIHEC, Vetranovićeva crkvena prikazanja, Riječ, 4 (2), 1998, 123-130.

Frano ČALE, Marin Držić: djela. Dundo Maroje i pripadajuće bilješke, Zagreb, 1987.

Valnea DELBIANCO, Biblijske žene u hrvatskoj književnosti srednjeg vijeka i renesanse, Narodna umjetnost, 43, br. 2, 2006, 135-148.

Džore DRŽIĆ, Draža je od zlata, u: Mirko Deanović (ur.) Stari pisci hrvatski. Knjiga 33: Džore Dř̌ić. Pjesni ljuvene, 15, Zagreb, JAZU, 1965.

Marin DRŽIĆ, Dundo Maroje, u: Milan Ratković (ur.) Pet stoljeća hrvatske književnosti. Knjiga 6: Marin Držić, Zagreb, 1962, 185-318.

Davor DUKIĆ, Sultanova djeca. Predodžbe Turaka u hrvatskoj književnosti ranog novovjekovlja, Zadar, 2004.

Dubravka DULIBIĆ-PALJAR, Kritička recepcija Robinje Hanibala Lucića od 1869. do 2011, Zadar, Croatica et slavica Iadertina, 2012.

Ignjat ĐURĐEVIĆ, Uzdasi Mandalijene pokornice, u: Franjo Švelec (ur.) Pet stoljeća hrvatske književnosti. Knjiga 18: Ignjat Đurđević, Zagreb, 1971, 257-357.

Dunja FALIŠEVAC, Stil hrvatske barokne epike, Dani Hvarskoga kazališta, 20, br. 1, 1994, 39-49.

Dunja FALIŠEVAC, Kaliopin vrt: studije u hrvatskoj epici, Split, 1997.

Dunja FALIŠEVAC, Dživo Bunić Vučić - pogovor, u: Dživo Bunić Vučić, Izabrane pjesme, Zagreb, 1998, 107-115.

Dunja FALIŠEVAC, Dubrovnik - otvoreni i zatvoreni grad. Granice mimesisa, granice fantastike: drukčija bića u književnosti staroga Dubrovnika, Zagreb, 2007.

Dunja FALIŠEVAC, Suze sina razmetnoga, u: Dunja Detoni-Dujmić i sur. (ur.) Leksikon hrvatske književnosti: Djela, Zagreb, 2008, 840-841. 
Dunja FALIŠEVAC, Jesu li Držićeve žene imale renesansu?, u: Romana Horvat (ur.) Slike starog Dubrovnika: filološke i književnoantropološke studije, Zagreb, 2013, 135-204.

Marin FRANIČEVIĆ et al., Povijest hrvatske književnosti: od renesanse do prosvjetiteljstva, Zagreb, 1974.

Marin FRANIČEVIĆ, Povijest hrvatske renesansne književnosti, Zagreb, 1983.

Ivan GUNDULIĆ, Dubravka, u: Jakša Ravlić (ur.) Pet stoljeća hrvatske književnosti. Knjiga 13. Prvi dio: Ivan Gundulić, Zagreb, 1962, 83-151.

Ivan GUNDULIĆ, Suze sina razmetnoga, u: Jakša Ravlić (ur.) Pet stoljeća hrvatske književnosti. Knjiga 13. Prvi dio: Ivan Gundulić, Zagreb, 1962, 39-82.

Ivan GUNDULIĆ, Osman, u: Milan Ratković (ur.) Pet stoljeća hrvatske književnosti. Knjiga 13. Drugi dio: Ivan Gundulić, Zagreb, 1964, 7-325.

Ante JURETA, Demonska bića u Zagori, Ethnologica Dalmatica, 24, br. 1, 2017, 43-57.

Nikica KOLUMBIĆ, Poticaji i nadahnuća: studije i eseji iz starije hrvatske književnosti, Zagreb, 2005.

Mihovil KOMBOL - Slobodan PROSPEROV NOVAK, Hrvatska književnost do narodnog preporoda, Zagreb, 1996.

Hanibal LUCIĆ, Robinja, u: Marin Franičević (ur.) Pet stoljeća hrvatske književnosti. Knjiga 7: Hanibal Lucić, Zagreb, 1968, 63-98.

Marko MARULIĆ, Judita, u: Ivan Slamnig (ur.) Pet stoljeća hrvatske književnosti. Knjiga 4: Marko Marulić, Zagreb, 1970, 37-91.

Marko MARULIĆ, Suzana, u: Ivan Slamnig (ur.) Pet stoljeća hrvatske književnosti. Knjiga 4: Marko Marulić, Zagreb, 1970, 107-124.

Šiško MENČETIĆ, Blaženi čas i hip, u: Rafo Bogišić (ur.) Pet stoljeća hrvatske književnosti. Knjiga 5: Zbornik stihova XV. i XVI. stoljeća, Zagreb, 1968, 82.

Hrvojka MIHANOVIĆ-SALOPEK, Značenje Marulićevih himana za razvoj hrvatske himnodije, Dani hvarskog kazališta - Marko Marulić, Split, 1989, 221-237; Isto: Mogućnosti, XXXVII, br. 1-2, Split, 1789, 141-154.

Anto MIŠIĆ, Žena u spisima ranokršćanskih pisaca, Obnovljeni život, 45, br. 6, Zagreb, 1990, 495-510.

Milan MOGUŠ, Rječnik Marulićeve Judite, Institut za hrvatski jezik i jezikoslovlje, Zagreb, 2001.

Divna MRDEŽA ANTONINA, Suzana, u: Dunja Detoni-Dujmić i sur. (ur.) Leksikon hrvatske književnosti: Djela, Zagreb, 2008, 838-839.

Mira MUHOBERAC, Suzana čista, u: Dunja Detoni-Dujmić i sur. (ur.) Leksikon hrvatske književnosti: Djela, Zagreb, 2008, 839.

Junije PALMOTIĆ, Armida, u: Armin Pavić (ur.) Stari pisci hrvatski. Knjiga 13. Drugi dio: Djela Gjona Gjora Palmotića, Zagreb, JAZU, 1883, 411-447.

Junije PALMOTIĆ, Pavlimir, u: Rafo Bogišić (ur.) Pet stoljeća hrvatske književnosti. Knjiga 9: Junije Palmotić, Zagreb, 1965, 251-364. 
Antun PAVEŠKOVIĆ, Topos "pravoga puta" u duhovnom pjesništvu Vetranovića, Dimitrovića i Nalješkovića, Anali Dubrovnik, 38, 2000, 165-184.

Mikša PELEGRINOVIĆ, Jeđupka, u: Rafo Bogišić (ur.) Pet stoljeća hrvatske književnosti. Knjiga 5: Zbornik stihova XV. i XVI. stoljeća, Zagreb, 1968, 109-133.

Božidar PETRAČ, Svevremenost poruke Ivana Gundulića, Obnovljeni život, 44, br. 5, Zagreb, 1989, 458-465.

Božidar PETRAČ, Lik žene u hrvatskoj književnosti, Bogoslovska smotra, 60, br. 3-4, Zagreb, 1991, 348-354.

Ana PROLIĆ KRAGIĆ, Laura, u: Slobodan Prosperov Novak i sur. (ur.) Leksikon Marina Držića, Zagreb, Leksikografski zavod Miroslav Krleža, 2009, 430.

Ana PROLIĆ KRAGIĆ, Petrunjela, u: Slobodan Prosperov Novak i sur. (ur.) Leksikon Marina Držića, Zagreb, Leksikografski zavod Miroslav Krleža, 2009, 585.

Milivoj SOLAR, Povijest svjetske književnosti, Zagreb, 2003.

Milivoj SOLAR, Karakterizacija lika, u: Jelena Hekman (ur.) Književni leksikon: Pisci. Djela. Pojmovi, Zagreb, 2007, 180-181.

Milivoj SOLAR, Lik, u: Jelena Hekman (ur.) Književni leksikon: Pisci. Djela. Pojmovi, Zagreb, 2007, 211-212.

Milivoj SOLAR, Dubravka, u: Romana Horvat (ur.) Književni leksikon: Pisci. Djela. Pojmovi, Zagreb, 2011, 123.

Milivoj SOLAR, Judita, u: Romana Horvat (ur.) Književni leksikon: Pisci. Djela. Pojmovi, Zagreb, 2011, 228-229.

Slavica STOJAN, Vjernice i nevjernice: žene u svakodnevici Dubrovnika (1600-1815.), Zagreb-Dubrovnik, Prometej, 2003.

Milovan TATARIN, Bludnica i svetica: starohrvatska legenda o Mariji Egipćanki, Zagreb, 2003.

Milovan TATARIN, Uskraćeni užitak: o spolnim zabranama u hrvatskoj srednjovjekovnoj i ranovjekovnoj književnoj kulturi. Povijest hrvatskoga jezika. Književne prakse sedamdesetih. Zbornik radova 38. seminara Zagrebačke slavističke škole (ur. Krešimir Mićanović), Zagreb, 2010, 223-255.

Mirko TOMASOVIĆ, Pjesničke i poetičke osobitosti Marulićeve "Judite" - Marko Marulić: Judita, Split, 1988, 9-44.

Mirko TOMASOVIĆ, Marko Marulić Marul, Zagreb, Zavod za znanost i književnost Filozofskog fakulteta - Liber, 1989.

Mirko TOMASOVIĆ, Marko Marulić, Zagreb, 1994.

Mirko TOMASOVIĆ, Marko Marulić - Antologija, Zagreb, 2000.

Mavro VETRANOVIĆ, Suzana čista, u: Vatroslav jagić i sur. (ur.) Stari pisci hrvatski. Knjiga četvrta. Dio drugi: Pjesme Mavra Vetranića Čavčića, Zagreb, JAZU, 1872, 339-389. 


\section{JUDITH AND OTHER WOMEN IN CROATIAN RENAISSANCE AND BAROQUE LITERARY WORKS}

\section{Summary}

In the paper the wide spectrum of female figures of the most famous Croatian renaissance and baroque authors is analysed. The consideration of the figures is carried out with regards to the determinant literary-historical period, the manners of expression and the literary ideas or purposes of the figures within the writer's conception of the world. Renaissance authors idealised the female beauty, whilst baroque authors showed it in a dichotomous form: as a source of sinfulness (a consequence of moralistic didacticism), as well as a source of new and bold erotic imaginations or of spiritual and ethical virtues. The formation of five different kinds of women was noticed with regards to their stronger realistic, symbolic, allegorical or abstract nature: Petrarchist ladies, female warriors, good women, female whores and female enchantresses. Studied in particular is the position of Judith in the considered corpus. This work has always attracted the attention of literary theorists, as well as linguists because with it Croatian mediaeval literacy quickly transformed into authorial and national literature.

Keywords: renaissance, baroque, ladies, female warriors, good women, whores, enchantresses 